\title{
PÓŹNOŚREDNIOWIECZNA CERAMIKA NACZYNIOWA Z GRÓDKA STOŻKOWATEGO W GIECZNIE, GM. ZGIERZ, POW. ZGIERSKI, WOJ. LÓDZKIE
}

SŁowa KLuczowe: ceramika, motte, późne średniowiecze, Polska centralna KEYwords: pottery, motte, Late Middle Ages, central Poland

\section{INFORMACJE WSTĘPNE}

Grodzisko w Giecznie, gm. Zgierz, pow. zgierski, woj. łódzkie (ryc. 1) nie było znane archeologom aż do 2014 r. Nie zostało wymienione w podstawowym zestawieniu obiektów tego typu z obszaru Polski Środkowej przygotowanym przez Janinę Kamińską (1953), ani w kolejnych zestawieniach dotyczących reliktów rezydencji rycerskich z okresu średniowiecza i nowożytności (Kajzer 1980; 2004; Marciniak-Kajzer 2011), nie uwzględniono go też w ewidencji zabytków opartej o program Archeologicznego Zdjęcia Polski. W 2014 r. zidentyfikował je Paweł Zawilski z Instytutu Archeologii Uniwersytetu Łódzkiego, podczas przeglądania serwisu Geoportal.gov.pl, a ściślej warstwy z cieniowanym Numerycznym Modelem Terenu opracowanym na podstawie pomiarów skanowania laserowego z powietrza (ALS - Airborne Laser Scanning) wykonanego w ramach programu ISOK (Informatyczny System Osłony Kraju przed zagrożeniami, por. Banaszek 2014; Zapłata, Ptak 2015: 102-105) (ryc. 2). 20 kwietnia 2015 r. obiekt został poddany weryfikacji terenowej, z udziałem ówczesnego inspektora do spraw zabytków archeologicznych Wojewódzkiego Urzędu Ochrony Zabytków w Łodzi, Magdaleny Nowak, przy udziale Pawła Zawilskiego i Jerzego Sikory. Potwierdziła ona obecność charakterystycznej formy terenowej zlokalizowanej w dnie doliny rzeki Moszczenicy, na zachód od położonego już na wysoczyźnie drewnianego, barokowego kościoła św. Jakuba. Dno doliny w tym rejonie wykorzystywane jest obecnie jako łąki. Wspominana forma terenowa została wstępnie 


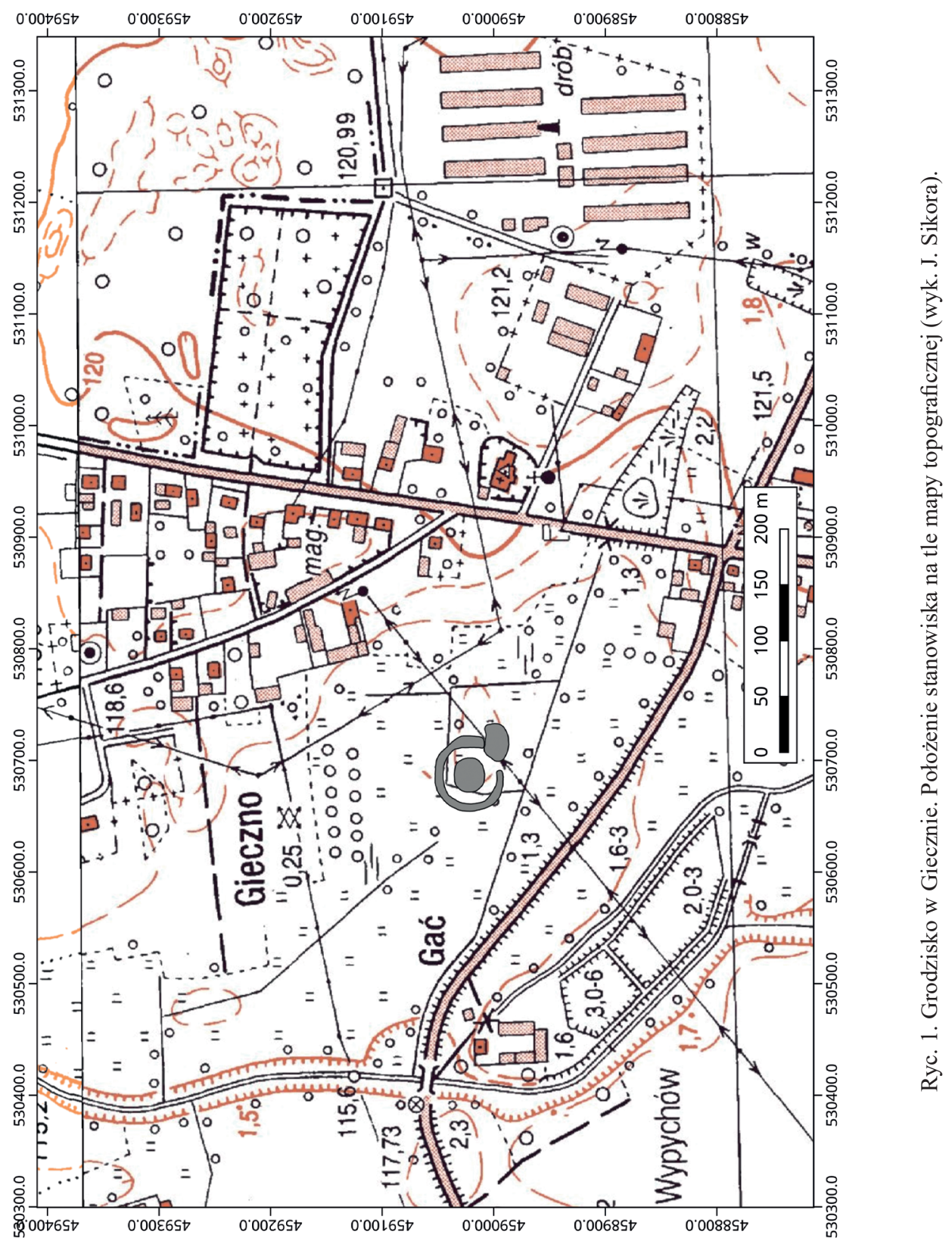


zinterpretowana jako relikt późnośredniowiecznego lub nowożytnego obiektu obronnego, tzw. grodziska stożkowatego.

Owa wstępna weryfikacja formy terenowej skłoniła Urząd do podjęcia decyzji o przeprowadzeniu sondażowych prac wykopaliskowych, które pozwoliłyby potwierdzić zaproponowaną atrybucję obiektu. Badania terenowe zrealizowano w okresie między 2 a 14 listopada 2015 r. przez zespół Pracowni Archeologiczno-Konserwatorskiej Aleksandra Andrzejewskiego i Tadeusza Grabarczyka, pod kierownictwem Jerzego Sikory. W pracach wzięli udział absolwenci i studenci Uniwersytetu Łódzkiego zatrudnieni w charakterze techników i eksploratorów.

W dnie doliny Moszczenicy w rejonie Gieczna znajduje się szereg niewielkich, suchych wyniesień, z których część ma charakter ostańców terasy. Obiekt położony jest na dwóch takich wyniesieniach. Na jednym z nich zlokalizowany jest owalny w planie, kopulasty nasyp o wymiarach 31 x $33 \mathrm{~m}$, o powierzchni około $890 \mathrm{~m}^{2}$, wyniesiony nie więcej niż 1,5 m względem dna doliny (wysokość kopca: 117,72 m n.p.m.). Wokół niego znajduje się fosa o szerokości około 8 do $10 \mathrm{~m}$, za którą czytelny jest niski (nie przekraczający wysokości $0,5 \mathrm{~m} \mathrm{w}$ relacji do dna fosy i dna doliny) dookolny wał, przerwany w południowo-wschodniej

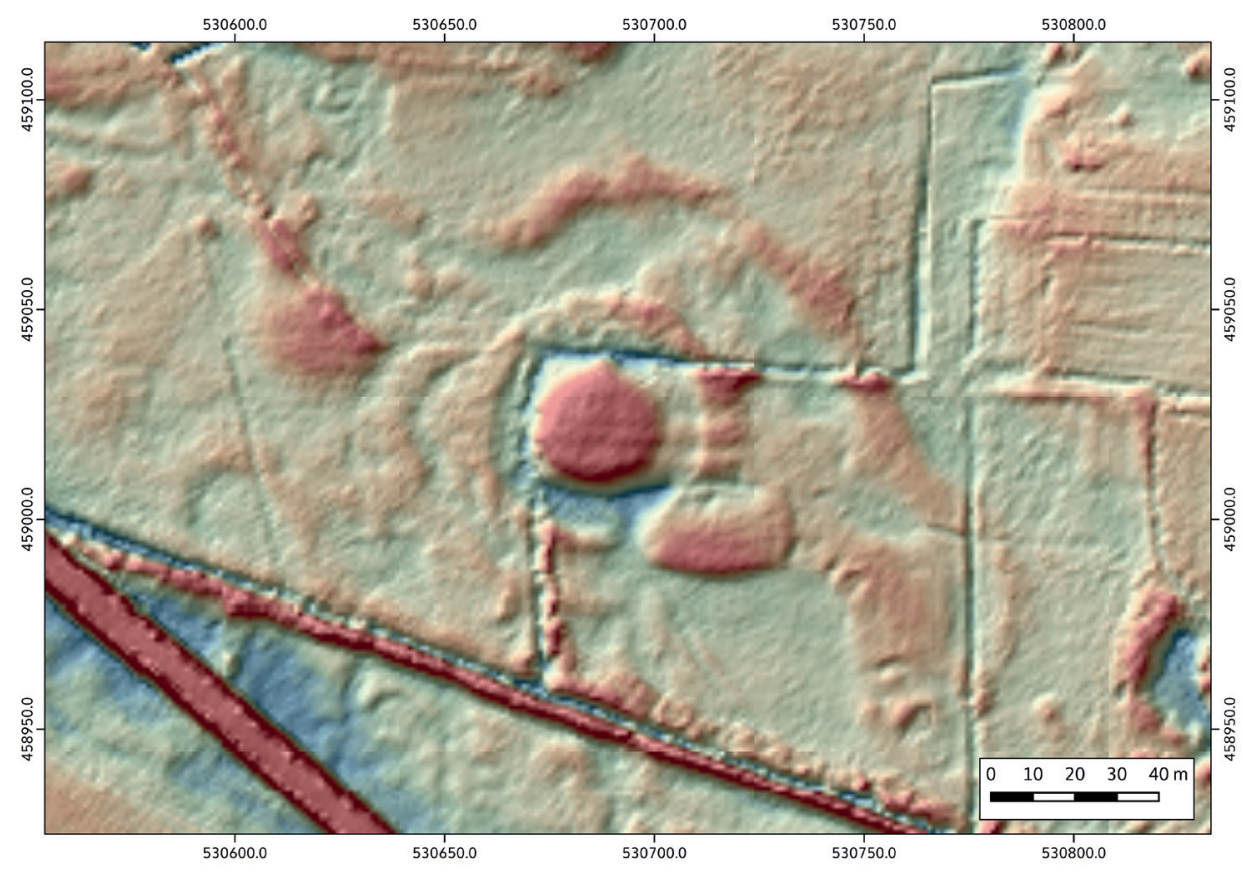

Ryc. 2. Grodzisko w Giecznie. Numeryczny Model Terenu na podstawie pomiarów lotniczego skanowania laserowego (Airborne Laser Scanning) w programie ISOK w wizualizacji barwnej Simplified Local Relief z nałożonym cieniowaniem zboczy (Hillshading; azymut $315^{\circ}$, kąt $45^{\circ}$ ) (wyk. J. Sikora). 
partii przebiegu. W tym miejscu zarejestrowano obecność kolejnego niewielkiego, owalnego wyniesienia, o wymiarach około 23,4 x 37,9 m oraz wysokości do 117,29 m n.p.m. Ma ono także charakter naturalny, choć mogło być przekształcone przez człowieka. Przed przystąpieniem do badań założyliśmy, że nasyp stanowi relikt kopca, na szczycie którego znajdowała się siedziba obronno-rezydencjonalna. Całość otoczona była fosą i zewnętrznym wałem, prawdopodobnie nasypanym $\mathrm{z}$ materiału wybieranego $\mathrm{z}$ fosy. Na owalnym wyniesieniu spodziewaliśmy się reliktów ewentualnego zaplecza mieszkalno-gospodarczego rezydencji. W celu zweryfikowania tych założeń oraz ustalenia podstawowej chronologii i stratygrafii stanowiska zdecydowaliśmy się otworzyć dwa wykopy badawcze (ryc. 3):

- Wykop 1, o wymiarach 1,5 x 35 m, który przecinał nasyp stożka w południowej części, przez fosę, wał dookolny aż po teren przylegający bezpośrednio na południe. Wykop ten podzielono na odcinki o długości $5 \mathrm{~m}$, oznaczone kolejnymi literami alfabetu od północy, od ,a” do „g”. Z powodu problemów technicznych podczas odhumusowania niektóre odcinki uzyskały szerokość nieco większą niż 1,5 m (maksymalnie do 1,8 m).

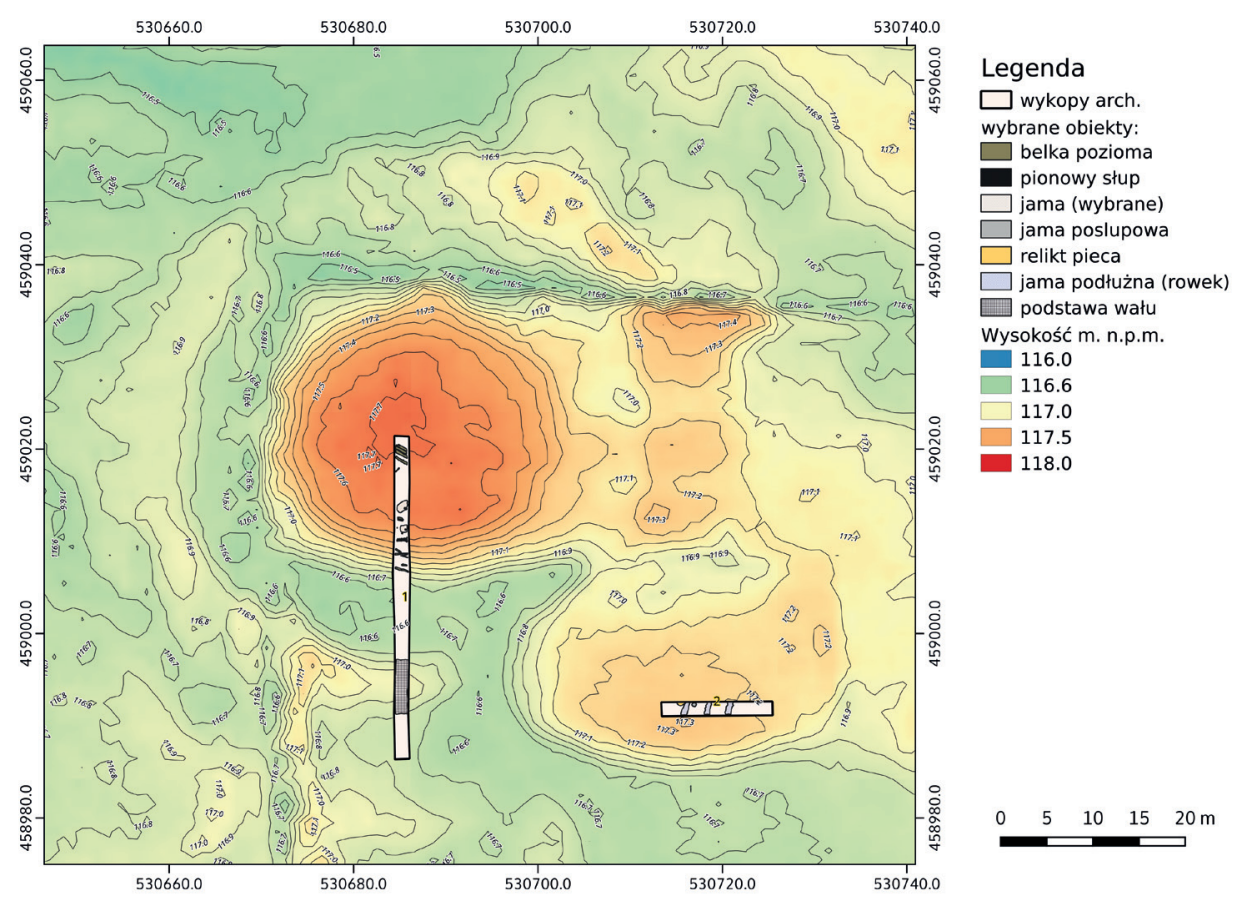

Ryc. 3. Grodzisko w Giecznie. Plan warstwicowy na podstawie Numerycznego Modelu Terenu z pomiarów ALS w programie ISOK z zaznaczonym położeniem wykopów archeologicznych oraz schematycznym położeniem wybranych struktur archeologicznych (wyk. J. Sikora). 
- Wykop 2, położony na wschód od wykopu 1 , na obszarze owalnego wyniesienia, miał wymiary $12 \times 1,5 \mathrm{~m}$.

Łączna powierzchnia wykopów wyniosła $70,5 \mathrm{~m}^{2}$. Wykonano ponadto zestaw zdjęć lotniczych za pomocą drona (zrealizowanych przez Piotra Wronieckiego), niestety z powodu mało korzystnych warunków (duża wilgotność gleby, słabo czytelne wyróżniki fotointerpretacyjne), nie dostarczyły one nowych, istotnych informacji. Dokonano także analizy Numerycznych Modeli Terenu ze skanowania laserowego z powietrza, posługując się programami QGIS, SAGA GIS oraz RVT. W trakcie tych działań wykonano mapy cieniowania zboczy (hillshading) oraz wielokierunkowego cieniowania zboczy (multidirection hillshading), a także wizualizacje SVF (sky view factor), SLRM (simplified Local Relief Model), LD (Local Dominance) i TPI (topographic position index), jak również analizę gradientu nachylenia stoków. Pozwoliły one na dokładniejszą ocenę zachowanej formy terenowej oraz morfologii doliny Moszczenicy w rejonie obiektu wraz z rejestracją licznych śladów paleokoryt i wyniesień (najpewniej o charakterze ostańców terasowych) w dnie doliny oraz jej krawędzi i przyległych obszarów wysoczyznowych, na których rozłożona jest współczesna wieś. Dane te pomogły także w precyzyjnym zaplanowaniu wykopów.

Badania prowadzono metodą eksploracji warstw naturalnych, uzupełnianą o metodę warstw arbitralnych (mechanicznych) tam, gdzie było to konieczne, $\mathrm{np}$. w trakcie badania nawodnionych poziomów wypełniska fosy. Obserwacje stratygraficzne rejestrowano w programach Strati 5 oraz Stratify 1.5 in situ, za pomocą przenośnego tabletu. Dokumentację w całości realizowano metodami cyfrowymi z wykorzystaniem oprogramowania fotogrametrycznego Agisoft Photoscan i aparatu Sony A57 oraz fotopunktów indywidualnie domierzanych za pomocą urządzenia GPS RTK Hi-Target v30. Uzyskane dzięki temu dwuwymiarowe ortofotoplany oraz wyniki pomiarów geodezyjnych integrowano w ramach jednego Systemu Informacji Geograficznej (GIS) opartego o program QGIS. Eksplorację silnie nawodnionych nawarstwień fosy prowadzono $\mathrm{z}$ wykorzystaniem pompy spalinowej stale odprowadzającej wodę.

Mimo ograniczonego zakresu badań, służącego przede wszystkim weryfikacji tez zaproponowanych na podstawie analizy danych ALS i przeglądu stanowiska $\mathrm{w}$ terenie, udało się rozpoznać zarówno podstawową stratygrafię, jak i pozyskać względnie bogaty zbiór materiału ruchomego, na który składały się przede wszystkim fragmenty naczyń ceramicznych i nieliczne przedmioty metalowe oraz kościane/rogowe. Pobrano także próby do datowań dendrochronologicznych i radiowęglowych.

W niniejszym tekście zaprezentowana zostanie przede wszystkim analiza materiału ceramicznego, w powiązaniu z podstawowymi obserwacjami straty- 
graficznymi i wynikami datowań niezależnych oraz informacjami ze źródeł pisanych. Należy traktować go jako wstępny komunikat i podstawę dla dalszych publikacji, w których przedstawione zostaną bardziej szczegółowe dane na temat stratygrafii i chronologii, a także szersze informacje dotyczące tła środowiskowego położenia obiektu.

\section{Historia MiEJSCOWości}

Miejscowość po raz pierwszy w źródłach pisanych odnotowana została w połowie XIV w. (mylnie jako „Bieczno”). Stanowiła wówczas własność przedstawicieli rodu Toporczyków. W 1369 r. należała do braci Sieciecha i Boguty, którzy w tym czasie dokonali podziału majątku dóbr Gieczno (Matriculorum... 1915, nr 167; Kozierowski 1926: 109; S. Zajączkowski, S.M. Zajączkowski 1966: 84; Nowak 2003: 201). W końcu XIV w. właścicielami wsi byli czterej bracia: Aleksander, stolnik łęczycki w latach 1388-1407 (Bieniak, Szymczakowa 1985, nr A 332), Piotr (Pietrasz), Żegota i Nawój. W pierwszej połowie XV w. na Giecznie dziedziczył Mikołaj, syn Nawoja. Działy w Giecznie miała także w tym czasie Dorota, córka Żegoty. Po Mikołaju dziedziczył syn Stanisław, natomiast po Dorocie synowie Mikołaj i Mikołaj Długi (Nowak 2003: 205-206, 512, 523, 551, 572).

Na początku wieku XVI właścicielami miejscowości byli przedstawiciele rodziny Modlińskich herbu Tępa Podkowa (Laski 1881: 409-410). W pierwszej ćwierci XVI w. w nieznanych bliżej okolicznościach w posiadanie udziałów w Giecznie oraz Sypinie weszli także Lasoccy z Brzezin herbu Dołęga, którzy wypuszczali gieczeńskie dobra $\mathrm{w}$ dzierżawę. W $1551 \mathrm{r}$. dzierżawcą, $\mathrm{z}$ ramienia Lasockich, był Marek Łubnicki. Zbudował on w Giecznie nowy dwór i młyn Borowiec.

Około połowy XVI w. części w Giecznie posiadali nadal Modlińscy oraz Brykcy Pokrzywnicki herbu Grzymała (Uruski i in. 1917: 1715), który zapewne zakupił je od Lasockich, a już w 1565 r. sprzedał Mikołajowi Maszkowskiemu (Tomczak 1997: 115). W 1576 r. udziały w Giecznie należały do syna Jakuba Modlińskiego oraz wymienionego powyżej Mikołaja Maszkowskiego (Pawiński 1883: 59-60).

W 1600 r. Jan i Maciej Maszkowscy, synowie Mikołaja, odkupili drugą część dóbr od Jana Modlińskiego, syna Jakuba. Natomiast w 1603 r. przy podziale majątku po ojcu Gieczno przypadło Janowi i jego żonie Barbarze Żelskiej. Para ta pozostawiła pięciu synów, którzy bardzo szybko zaczęli wypuszczać swoje działy w Giecznie w zastawy oraz sprzedawać je. Finalnie w posiadanie dóbr gieczeńskich weszli w 1678 r. jako jedyni właściciele Pokrzywniccy - bracia Kazimierz i Jan (Tomczak 1997: 116-117). 
Jan Pokrzywnicki - kanonik gnieźnieński, proboszcz krakowski i złakowski, ufundował, zachowany do czasów obecnych, drewniany kościół parafialny wzniesiony w latach 1717-1721. Jan zakończył żywot jeszcze w $1717 \mathrm{r}$. (Łoziński 1954: 72-73; Łaski 1881: 409). Jego bratem był Kazimierz, miecznik łęczycki w latach 1677-1718, zmarły w 1718 r. (Żerek-Kleszcz 1993, nr 411), po którym dziedziczył syn Jan, zmarły przed 1725 r. (Uruski i in. 1917: 175-176).

W 1717 r. Maszkowscy rozpoczęli wieloletni proces o Gieczno z Pokrzywnickimi, zakończony dopiero ugodą zawartą w 1785 r. przy udziale sądu polubownego, który definitywnie przyznał dobra gieczeńskie Pokrzywnickim (Tomczak 1997: 118).

W końcu XVIII w. na Giecznie dziedziczyła Helena z Pokrzywnickich, córka Jana, żona Karola Gomolińskiego herbu Jelita (Uruski i in. 1917: 175-176), a następnie na początku XIX w. ich córka Józefata, żona Szymona Dzierzbickiego, wojewody łęczyckiego. Po bezpotomnej śmierci Józefaty w 1823 r. dobra gieczeńskie przeszły w ręce Gomolińskich (Tomczak 1997: 118-119). Ostatnim właścicielem w czwartej ćwierci XIX w. był H. (Henryk) Gomoliński herbu Jelita (Sęczys 2000: 190). Na początku XX w. dobra rozparcelowano tworząc trzy folwarki. Ten w Giecznie objęła rodzina Jaworskich (Tomczak 1997: 119).

\section{PODSTAWOWE INFORMaCJE O STRATYGRafi OBIEkTU}

Prace przeprowadzone w wykopie 1 pozwoliły jednoznacznie na wydzielenie dwóch, następujących po sobie faz zagospodarowania terenu niewielkiego wyniesienia (ostańca terasy). W fazie I był to najpewniej obiekt o charakterze pierścieniowym, otoczony drewnianą palisadą wykonaną z tępo zakończonych półokrąglaków o średnicy 16 do $20 \mathrm{~cm}$, ustawionych ukośnie do wnętrza na krawędzi fosy, wkopanych w podłoże na głębokość do około $0,5 \mathrm{~m}$ (ryc. 4). Były one obsypane nawarstwieniami piaszczysto-gliniastych, niewysokich wałów (jednostki stratygraficzne (dalej: j.s.) 29, 40), wzmocnionych dodatkowo kamiennymi nasypiskami (j.s. 35 i 53). Owe kamienne nasypiska częściowo nawarstwiały się (zapewne z powodu erozji i rozsypania do wnętrza obiektu) na drewniane konstrukcje, noszące ślady oddziaływania ognia (co istotne - ślady te nie były czytelne na półokrąglakach palisady). Tworzyły one układ przebiegających równolegle do siebie, skośnie do ścian wykopu, dranic oraz belek (j.s. 62, $63,64,65)$. Sugerują one istnienie w tym miejscu drewnianej zabudowy.

W fazie II, na opisanych reliktach oraz przykrywającym je poziomie próchnicznym (j.s. 41) usypano kopiec, o trudnej do ustalenia pierwotnej wysokości. Tworzyły go piaszczyste i gliniaste poziomy nasypowe (j.s. 2, 3, 4) oraz nasypowe - porozbiórkowe (j.s. 28, 38, 42). Wszystkie zawierały głównie cera- 


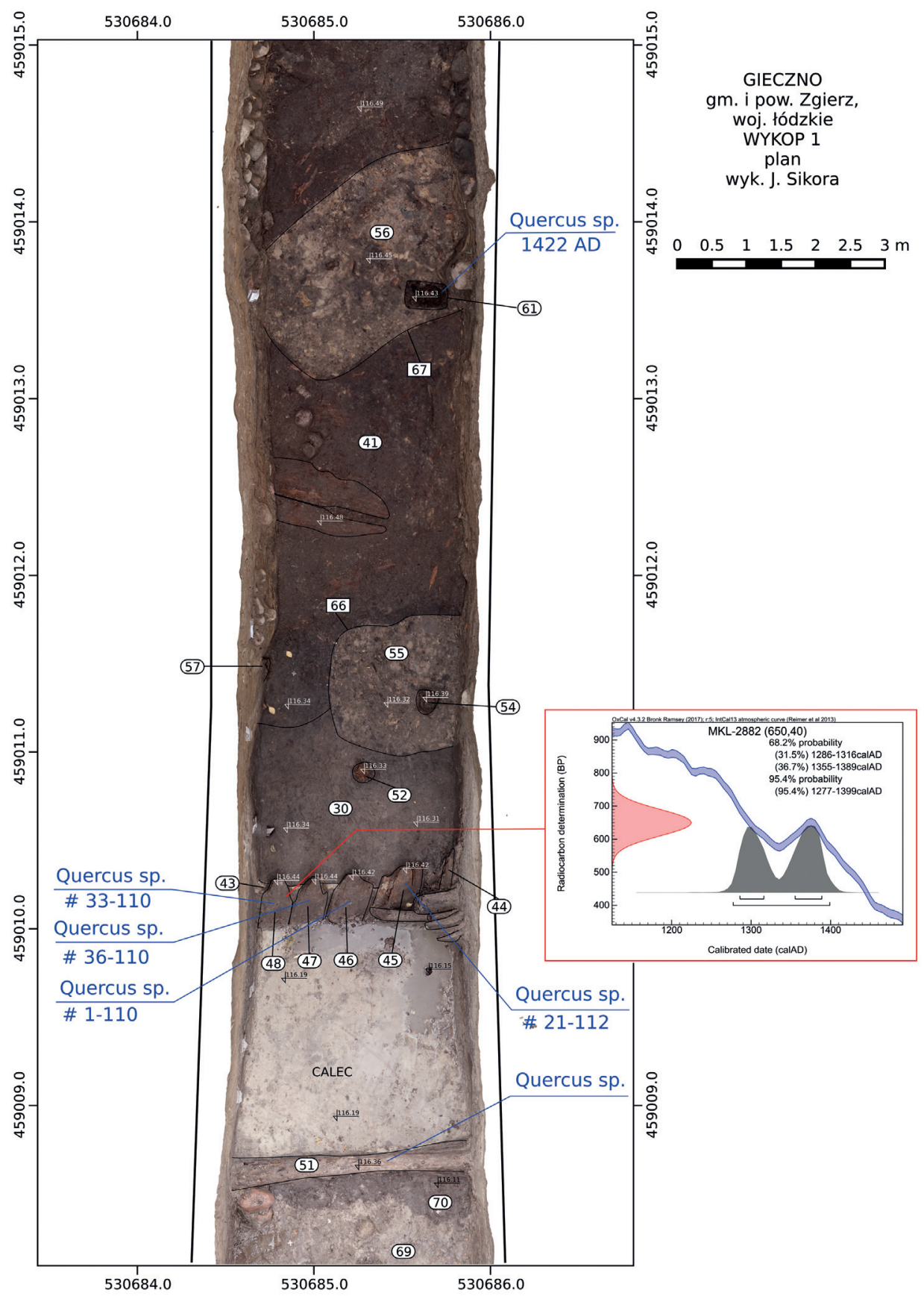

Ryc. 4. Grodzisko w Giecznie, wykop 1, ortofotoplan struktur archeologicznych odsłoniętych w odcinkach b i c (wyk. J. Sikora). 
miczny materiał zabytkowy, pojedyncze zabytki metalowe, w tym bełt grotu kuszy i okucie brązowe związane ze sprzączką pasa oraz liczne węgle drzewne i bryły polepy. Nasycenie materiałem zabytkowym, polepą i węglami drzewnymi wyraźnie wskazuje, że nawarstwienia te są wynikiem redeponowania starszych poziomów kulturowych. Być może pochodzą one z prac ziemnych wykonanych na powierzchni samego gródka lub z terenu owalnego wyniesienia $\mathrm{w}$ jego części południowo-wschodniej. $Z$ poziomów tych uformowano kopulasty nasyp z płaską powierzchnią, który stanowił, jak należy przypuszczać, podstawę pod budowlę rezydencjonalną. Jej reliktem jest zapewne gliniasta warstwa (j.s. 4) o miąższości $0,43 \mathrm{~m}$ zarejestrowana w północnej części wykopu. Stanowiła ona prawdopodobnie podbudowę pod drewnianą budowlę. Zachowana wysokość nasypu wynosi około 1,25 m, jednak bez wątpienia była większa. Numeryczny Model Terenu wyraźnie wskazuje, że część pierwotnego nasypu została zepchnięta w kierunku wschodnim, gdzie posłużyła do wyrównania powierzchni fosy.

Już od fazy I założeniu towarzyszyła fosa, o dość regularnym, trapezowatym przekroju, szerokości 11,5 m i niewielkiej głębokości, około $0,6-0,7 \mathrm{~m}$ poniżej średniowiecznej powierzchni gruntu (obecnie spąg zalega na głębokości około $1 \mathrm{~m})$. Na zewnątrz od niej rozciągał się nasyp niewysokiego wału ziemnego o szerokości około $4 \mathrm{~m}$ i wysokości $0,6 \mathrm{~m}$. Jego stratygrafia (obecność redeponowanych, naturalnych osadów dna doliny) wyraźnie wskazuje, że do usypania użyto materiału pozyskanego w trakcie kopania fosy. Sugeruje to, iż wał funkcjonował już w fazie I założenia.

Fosa wypełniona była w spągu poziomem piasków przewarstwianych mułkami organicznymi (j.s. 73). Na nich spoczywała dość cienka warstwa oliwkowo-szarej gytii lub mułków organicznych. Dopiero na tych dwóch osadach zalegały kolejne poziomy torfów (j.s. 5, 11, 69, 70). Pomiędzy nimi zaobserwowano obecność przynajmniej dwóch przewarstwień piasków z domieszką mułków organicznych (j.s. 6 i bardziej miąższa 72), stanowiących zapewne osady o charakterze pozakorytowym. Wewnątrz rejestrowano, poza materiałem ceramicznym (zalegającym głównie w warstwie spągowej), liczne fragmenty organiczne: drewniane bale, gałęzie, żołędzie, liście oraz zabytek snycerski - drewnianą kulę zdobioną plecionkowym ornamentem, posiadającą trzpień. Element ten uznać można za fragment mebla. Opisany układ nawarstwień i ich charakter dość jednoznacznie poświadczają, iż pierwotnie fosa była wypełniona wodą, w której formowały się organiczne poziomy typowe dla środowisk jeziornych (gytia, mułki organiczne), stopniowo ulegające zarastaniu, tworząc poziomy torfów. Proces ten, trwający zapewne przez długie stulecia, był dwukrotnie przerwany epizodami powodziowymi, których świadectwem są warstwy osadów pozakorytowych. Podobną morfologię miały, przebadane w ostatnim czasie, wypełniska fos gródka w Rozprzy, gdzie dzięki licznym datowaniom radio- 
węglowym udało się, precyzyjnie schronologizować ten proces (por. Kittel i in. 2018). Wyraźną różnicą jest obecność w Giecznie poziomów pozakorytowych. W Rozprzy udało się taki poziom zidentyfikować dopiero dla późnego okresu nowożytnego (XVIII-XIX w.).

$\mathrm{Na}$ terenie owalnego wyniesienia $\mathrm{w}$ południowo-wschodniej linii przebiegu dookolnego wału zarejestrowano wyraźne poziomy destrukcji zabudowy drewniano-glinianej (najpewniej szachulcowej) (ryc. 5). W ich stropie wyróżnić można było podłużne rowki szerokości $0,48 \mathrm{~m}$, wypełnione próchniczno-gliniastymi nawarstwieniami, równoległe do siebie, w odległości 1,8 m od siebie (j.s. 12, 19, 20). Stanowiły one zapewne relikt podwalin jakiegoś budynku. Nieco starszy, bo częściowo przecięty przez rowek 12, był zlokalizowany nieco na zachód piec, pierwotnie zapewne kopułowy, o nieznanym przeznaczeniu (j.s. 14, 21, 17, 18). W jego wypełnisku zaobserwowano, obok spalonych fragmentów drewna, także piaszczyste nawarstwienia, z dużą ilością węglanów wapnia. W okolicy zarejestrowano obecność dość licznych i dużych brył żużla. Może to wskazywać na jego związki z produkcją metalurgiczną. Piecowi towarzyszył od wschodu czworobocznie zaostrzony słup (j.s. 33), wbity w naturalne, piaszczyste podłoże ostańca, może pozostałość zadaszenia.

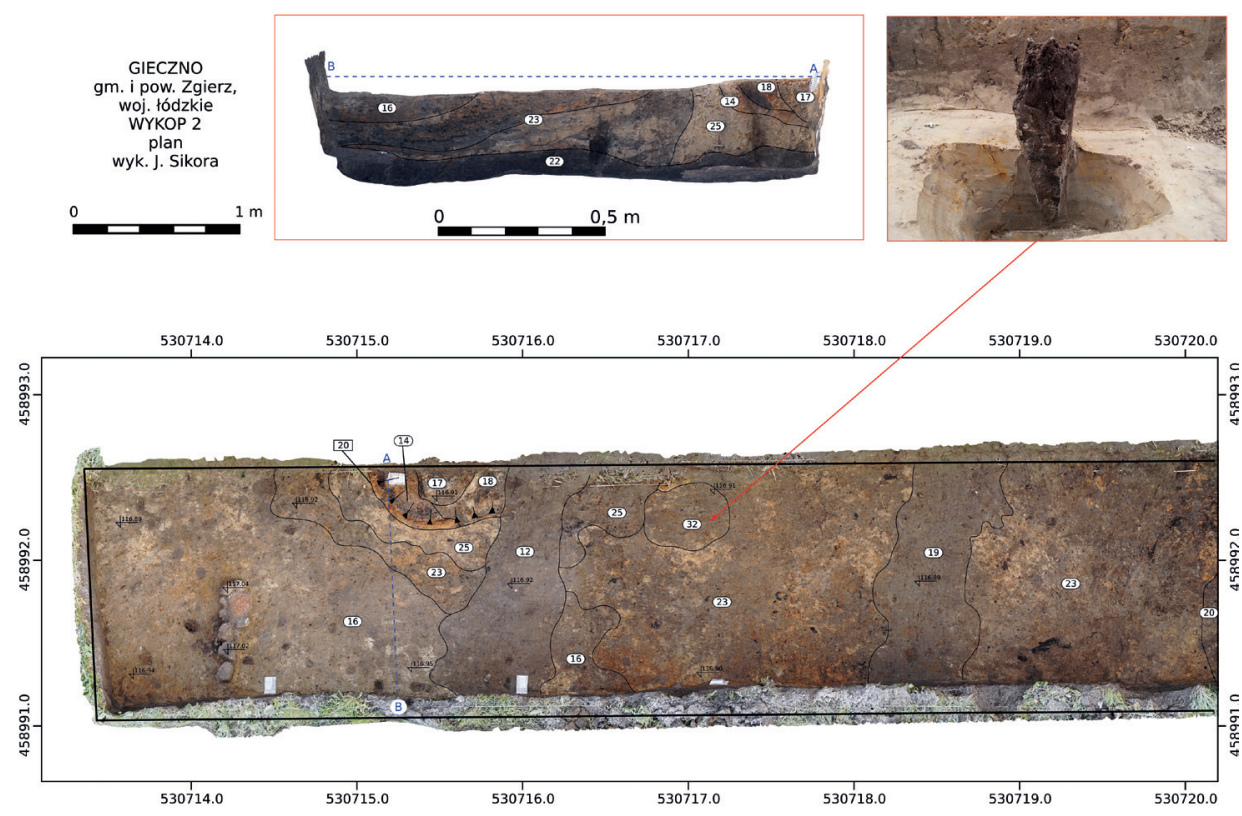

Ryc. 5. Grodzisko w Giecznie, wykop 2, ortofotoplan struktur archeologicznych w zachodniej i centralnej części wykopu (wyk. J. Sikora). 


\section{ChaRAKTERYSTYKA ZBIORU CERAMIKI NACZYNIOWEJ}

Zbiór zabytków z gródka stożkowatego objął łącznie 1472 fragmenty późnośredniowiecznych naczyń ceramicznych, 10 zabytków metalowych, 305 kości zwierzęcych, 8 bryłek polepy, 9 bryłek żużla żelaznego, wspomnianą już drewnianą kulę z trzpieniem, fragmenty skóry oraz orzechy laskowe i inne fragmenty organiczne pozyskane do analiz radiowęglowych. W dalszej części tekstu skupimy się na scharakteryzowaniu materiałów ceramicznych pozyskanych w trakcie badań.

W zbiorze ceramiki naczyniowej dominowały fragmenty należące do części środkowych naczyń (1180 ułamków), w znacznie mniejszym stopniu reprezentowane były krawędzie i szyje (153 fragmentów) oraz dna i części przydenne (127 ułamki). Udało się także wyróżnić: 10 ułamków pokrywek i 2 fragmenty taśmowatych uch dzbanów. Nie zachowało się żadne naczynie o pełnym profilu od krawędzi aż po dno.

\section{TYPOLOGIA CERAMIKI NACZYNIOWEJ}

Omawiany zbiór ceramiki był mało zróżnicowany pod względem form naczyń. Wyróżniono w nim bowiem jedynie fragmenty należące do garnków i dzbanów, sporadycznie miseczek, mniejszych naczyń garnuszków lub dzbanków oraz pokrywek. Rodzaje naczyń oznaczono wielkimi literami alfabetu G, D i M. Następnie, głównie na podstawie ukształtowania krawędzi wylewu i szyi, wyróżniono w poszczególnych grupach typy (oznaczane dużymi literami rzymskimi) i podtypy (oznaczane małymi literami). Dla pokrywek oraz mniejszych naczyń, których zidentyfikowano jedynie pojedyncze, niewielkie fragmenty nie udało się określić typów.

\section{G. Garnki}

G.I Typ obejmuje garnki o mniej lub bardziej wydętym brzuścu, rzadziej formy o profilu esowatym i krótkiej szyi wygiętej do wewnątrz. Krawędź wylewu jest silniej lub słabiej odwinięta na zewnątrz, szeroka, taśmowata, silniej lub słabiej profilowana. W typie tym wyróżniono 4 podtypy:

G.Ia Naczynia o słabiej profilowanej krawędzi wylewu bez okapu i wrębu;

G.Ib Garnki o słabiej lub silniej profilowanej krawędzi wylewu z zaznaczonym wrębem;

G.Ic Naczynia o słabiej lub silniej profilowanej krawędzi wylewu z zaznaczonym okapem, bez wrębu;

G.Id Garnki o silniej profilowanej krawędzi wylewu z okapem i wrębem.

G.II Zaliczono do niego garnki o krawędzi wylewu nieprofilowanej, zaokrąglonej, kwadratowej lub lekko wydłużonej ze słabo zaznaczonym wrębem lub wrębu pozbawione $\mathrm{w}$ dwóch podtypach: 
G.IIa Garnki o krawędzi wylewu z wrębem;

G.IIb Naczynia o krawędzi wylewu bez wrębu.

G.III Typ obejmuje naczynia o słabo profilowanej, niepogrubionej, lekko odgiętej na zewnątrz krawędzi wylewu ze słabo zaznaczonym wrębem.

G.IV Garnki z cylindryczną szyją.

\section{Dzbany}

D.I Dzbany o krawędzi wylewu nieprofilowanej, lekko wydłużonej, zagiętej ku środkowi.

\section{Miseczki}

M.I Naczynia o łagodnym, esowatym profilu, krótkiej szyi i krawędzi wylewu lekko odwiniętej na zewnątrz, pogrubionej, nieprofilowanej.

\section{GRUPY TECHNOLOGICZNE CERAMIKI NACZYNIOWEJ}

Analizy zbioru ceramiki dokonano w oparciu o system klasyfikacji materiałów ceramicznych zaproponowany przez Leszka Kajzera, wyróżniając grupy technologiczne oznaczone dużymi literami alfabetu od A do D (1986: 202; 1991: 469-470).

Najliczniejszy zespół, obejmujący 893 fragmenty (60,67\% ogółu materiałów - tabela 1, wykres 1) stanowily naczynia wypalone w atmosferze redukcyjnej (grupy technologiczne B i C). Odnotowano także znaczny udział ułamków wypalonych w słabo zaawansowanej atmosferze utleniającej grupy technologicznej D/A, do której zaliczono 416 fragmentów (28,26\% ogółu materiałów - tabela 1 , wykres 1 ). Nielicznie natomiast reprezentowane były naczynia wypalone

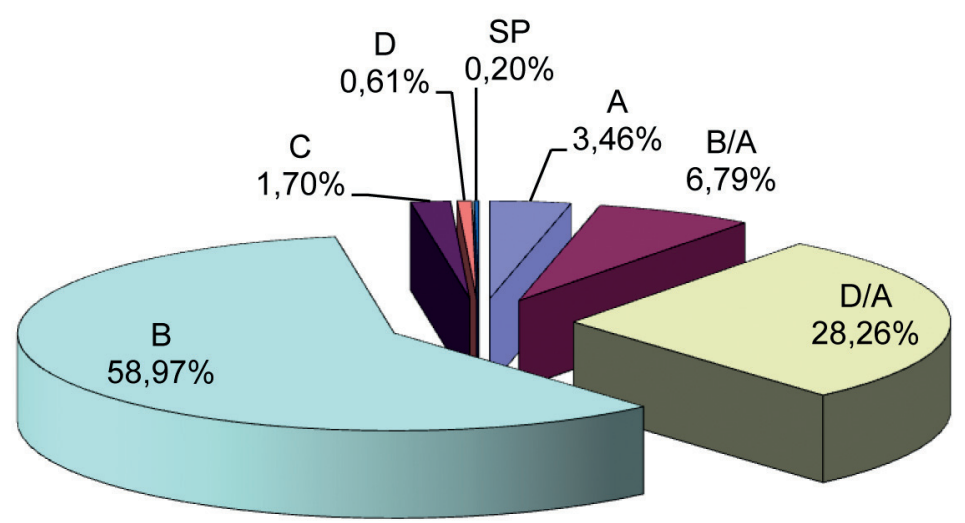

Wykres 1. Ceramika późnośredniowieczna z podziałem na grupy technologiczne (wykopy 1 i 2) (oprac. A. Nierychlewska). 
Tabela 1. Gieczno, gm, Zgierz, pow. zgierski, woj. łódzkie.

Zestawienie materiałów ruchomych z podziałem na warstwy (oprac. A. Nierychlewska).

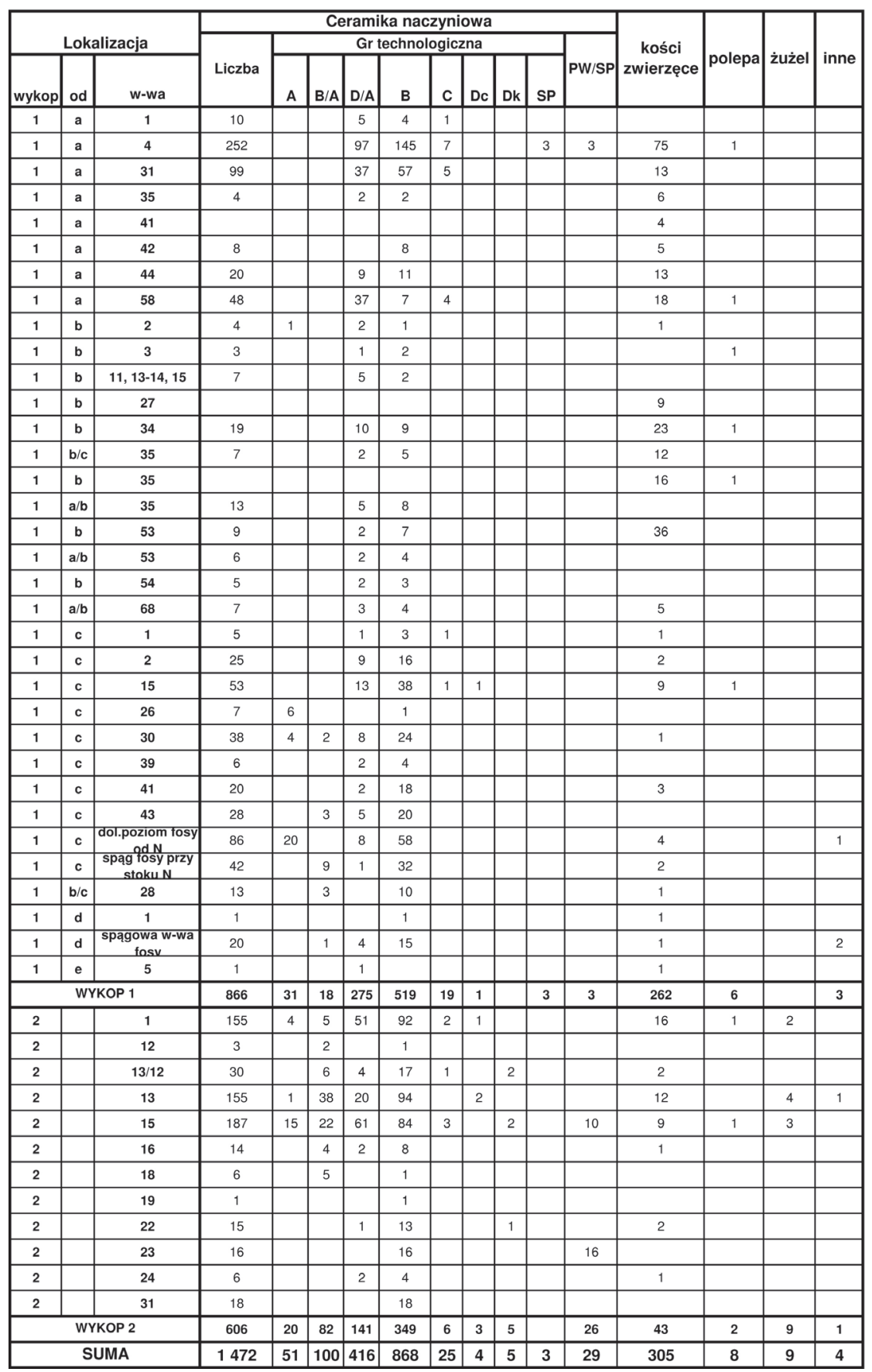


w słabo zaawansowanej atmosferze redukcyjnej (grupa technologiczna B/A) oraz wyroby nawiązujące $\mathrm{w}$ technice wykonania do metod produkcji stosowanych we wcześniejszych okresach (grupa technologiczna A). Do grupy B/A zaliczono 100 fragmentów (6,79\% ogółu materiałów - tabela 1, wykres 1), do grupy A - 51 ułamków (3,46\% ogółu - tabela 1, wykres 1$)$. Odnotowano także niewielki udział naczyń wypalonych w zaawansowanej atmosferze utleniającej grupy technologicznej D, liczący w sumie 9 fragmentów $(0,6 \%$ ogółu - tabela 1 , wykres 1), wśród których wyróżniono wyroby wykonane z glin żelazistych (grupa technologiczna Dc) oraz z glin lekkich, kremowych (grupa technologiczna Dk). Trzy ułamki były silnie przepalone wtórnie i spumeksowane w związku z czym nie nadawały się do dalszych analiz.

Naczynia wykonywano zarówno z glin żelazistych, jak i lżejszych, kremowych, techniką taśmowo-ślizgową, następnie całkowicie obtaczano na kole garncarskim.

Poniżej szczegółowa charakterystyka wyróżnionych grup technologicznych.

\section{Grupa A}

Nielicznie reprezentowana w omawianym zbiorze ceramiki, objęła zaledwie 51 fragmentów (3,46\% zbioru) (tabela 1, wykres 1). Naczynia wykonane były z masy garncarskiej schudzanej głównie domieszką piasku średnio i drobnoziarnistego z dodatkiem tłucznia, używaną w ilości średniej ( $92,2 \%$ ogółu fragmentów). Sporadycznie stosowano domieszkę piasku średnio i drobnoziarnistego $\mathrm{z}$ dodatkiem gruboziarnistego $\mathrm{w}$ ilości dużej (1 ułamek) oraz średnio i drobnoziarnistego z przewagą frakcji średnioziarnistej, w ilości średniej (3 fragmenty). Czerepy naczyń po wypale w słabo zaawansowanej atmosferze utleniającej przyjmowały barwę ciemnobrunatną, brunatno-brązową i brunatno-szarą. Wszystkie miały różnobarwne przełamy. Wyroby nosiły ślady intensywnego użytkowania w postaci okopconych od wewnątrz, zewnątrz lub obustronnie ścianek.

W grupie dominowały fragmenty pochodzące z części środkowych naczyń (39 ułamków), nieliczne były krawędzie (8 fragmentów) oraz dna i części przydenne (4 ułamki). Dna były płaskie, na obu zachowały się ślady podsypki z piasku. Zmierzona średnica dna dla jakiego udało się wykonać pomiar wynosiła $15 \mathrm{~cm}$ (ryc. 6: 2). Naczynia nie były bogato ornamentowane. Na 19 fragmentach odnotowano motywy jednowątkowe. Dominowały wśród nich płytsze lub głębsze żłobki dookolne, jeden ułamek zdobiony był nacięciami ukośnymi, kolejny rytymi znakami „X”. Na 10 fragmentach wystąpił dwuwątkowy motyw żłobków dookolnych w połączeniu z nacięciami ukośnymi. Wyroby te w technologii produkcji wyraźnie nawiązywały do naczyń wczesnośredniowiecznych, natomiast ich formy były analogiczne do późnośredniowiecznych.

Wśród form zaobserwowano jedynie fragmenty pochodzące z garnków należących do podtypów G.Id i G.IIb (ryc. 6: 1,3). W profilu od wylewu po część 


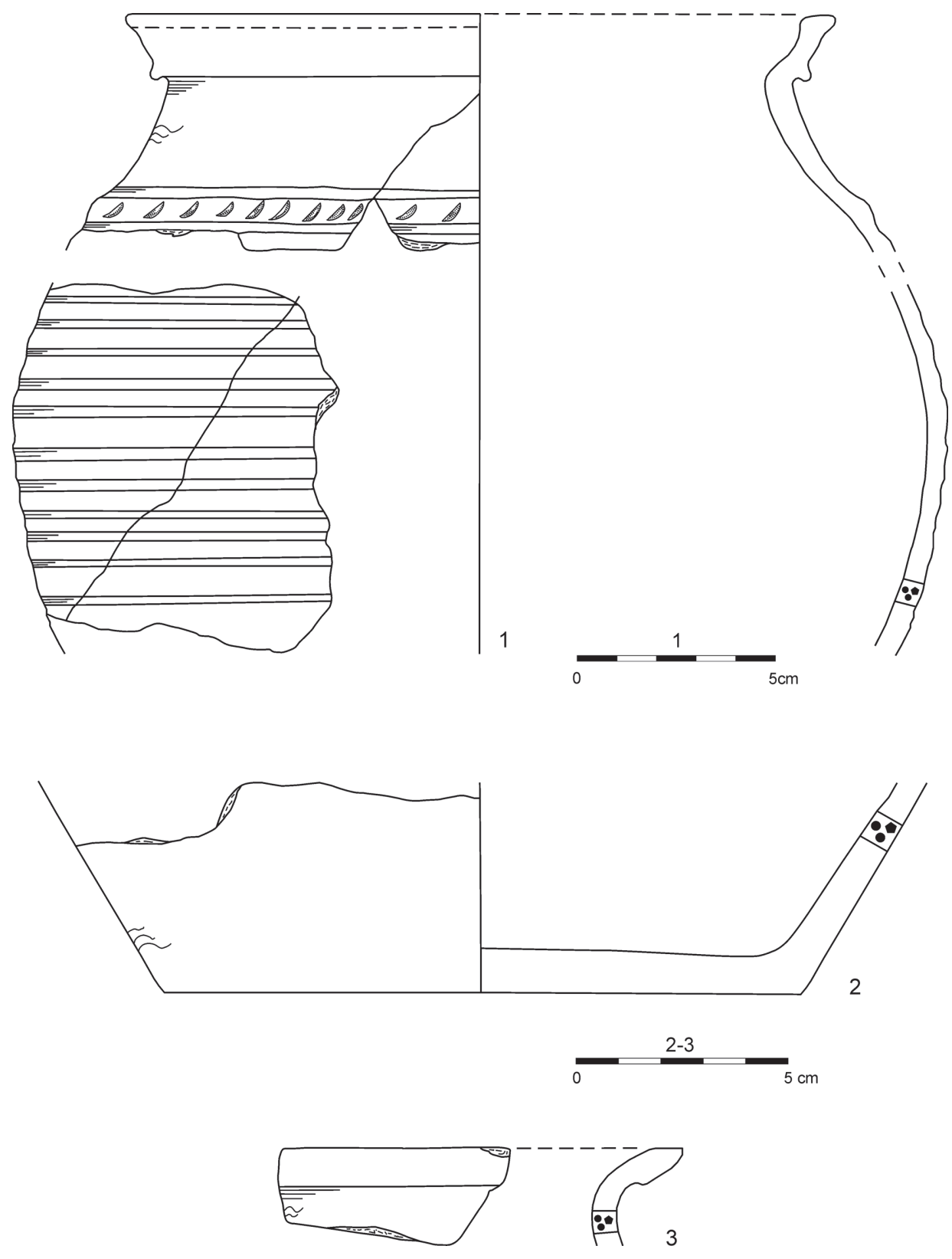

Ryc. 6. Gieczno, gm. Zgierz, pow. zgierski, woj. łódzkie. Wybór ceramiki naczyniowej grupy technologicznej A. 1) wykop 1, od. c, dolny poziom fosy, j.s. 73; 2) wykop 1, od. c, j.s. 26; 3) wykop 2, j.s. 15 (rys. A. Nierychlewska). 
poniżej największej wydętości brzuśca udało się zrekonstruować jedno naczynie - garnek podtypu G.Id o średnicy $18 \mathrm{~cm}$, zdobiony dwuwątkowym motywem żłobków dookolnych w połączeniu z nacięciami ukośnymi (ryc. 6: 1).

\section{Grupa D/A}

Druga pod względem liczebności grupa w zbiorze ceramiki. Zaliczonych do niej zostało 28,26\% ogółu materiałów (416 ułamków) (tabela 1, wykres 1). Obejmuje ona fragmenty naczyń wypalonych w słabo zaawansowanej atmosferze utleniającej, nadającej ściankom barwę beżową, beżowo-pomarańczową, beżowo-szarą lub pomarańczowo-szarą. Do schudzania gliny stosowano najczęściej piasek średnio i drobnoziarnisty z przewagą frakcji średnioziarnistej, w ilości średniej (71\%) oraz piasek drobno i średnioziarnisty z przewagą drobnoziarnistego, dodawany w ilości małej (24\%). Rzadziej używano piasku średnio i drobnoziarnistego z domieszką gruboziarnistego w ilości dużej (3,6\%) oraz piasku drobnoziarnistego w ilości średniej $(1,2 \%)$. Dominowały przełamy wielobarwne $(92,8 \%)$, tylko $7,2 \%$ wyrobów posiadało jednobarwne. Na ponad 90\% wyrobów zachowały się ślady związane z ich użytkowaniem w kuchni (okopcenia, wtórne przepalania).

Większość, bo aż 327 fragmentów należało do części środkowych naczyń, do krawędzi i szyi zaliczonych zostało 55 ułamków, a do den i części przydennych - 30. Zidentyfikowano także 4 fragmenty pokrywek. Dna były najczęściej ukształtowane płasko, sporadycznie obserwowano lekko wklęsłe. Na 11 ułamkach zachowały się ślady podsypki z piasku drobno lub średnioziarnistego (5 fragmentów) lub surowców organicznych (6 ułamków), pozostawiających na wypalonym naczyniu charakterystyczną ,dziurkowaną" fakturę. Na dnach obserwowano także sporadycznie inne ślady produkcji naczynia - pierścienie dookolne (5 fragmentów), podważania gotowego wyrobu od tarczy koła (4 ułamki) oraz odciski faktury koła, na którym lepiono naczynie (2 fragmenty). Zmierzone średnice den zawierały się w przedziale 9,4 do $12 \mathrm{~cm}$ (ryc. 7: 2; 9: 3). Naczynia grupy technologicznej D/A ornamentowane były oszczędnie. Zdobienie zaobserwowane na 173 ułamkach (stanowiących 41,6\% ogółu grupy), ograniczone było najczęściej do płytszych lub głębszych żłobków dookolnych (95,4\% ornamentowanych). Wśród motywów jednowątkowych wyróżniono jeszcze na 3 fragmentach rytą linię falistą, a na jednym odciskaną ,jodełkę". Na 4 ułamkach odnotowano ornamentowanie krawędzi naczynia odciskami dołków palcowych.

Wśród form naczyń udało się zidentyfikować fragmenty należące do garnków wszystkich z wyróżnionych typów, dzbanów typu D.I (ryc. 7: 1), niekiedy miseczek (typ M.I) i pokrywek. Wśród garnków najbardziej popularny był podtyp G.Ib (ryc. 8: 1; 9: 2, 4), rzadziej reprezentowane były podtypy G.Id (ryc. 7: 5-6) i G.Ia (ryc. 8: 3), sporadycznie notowano podtyp G.Ic (ryc. 8: 2). Nato- 

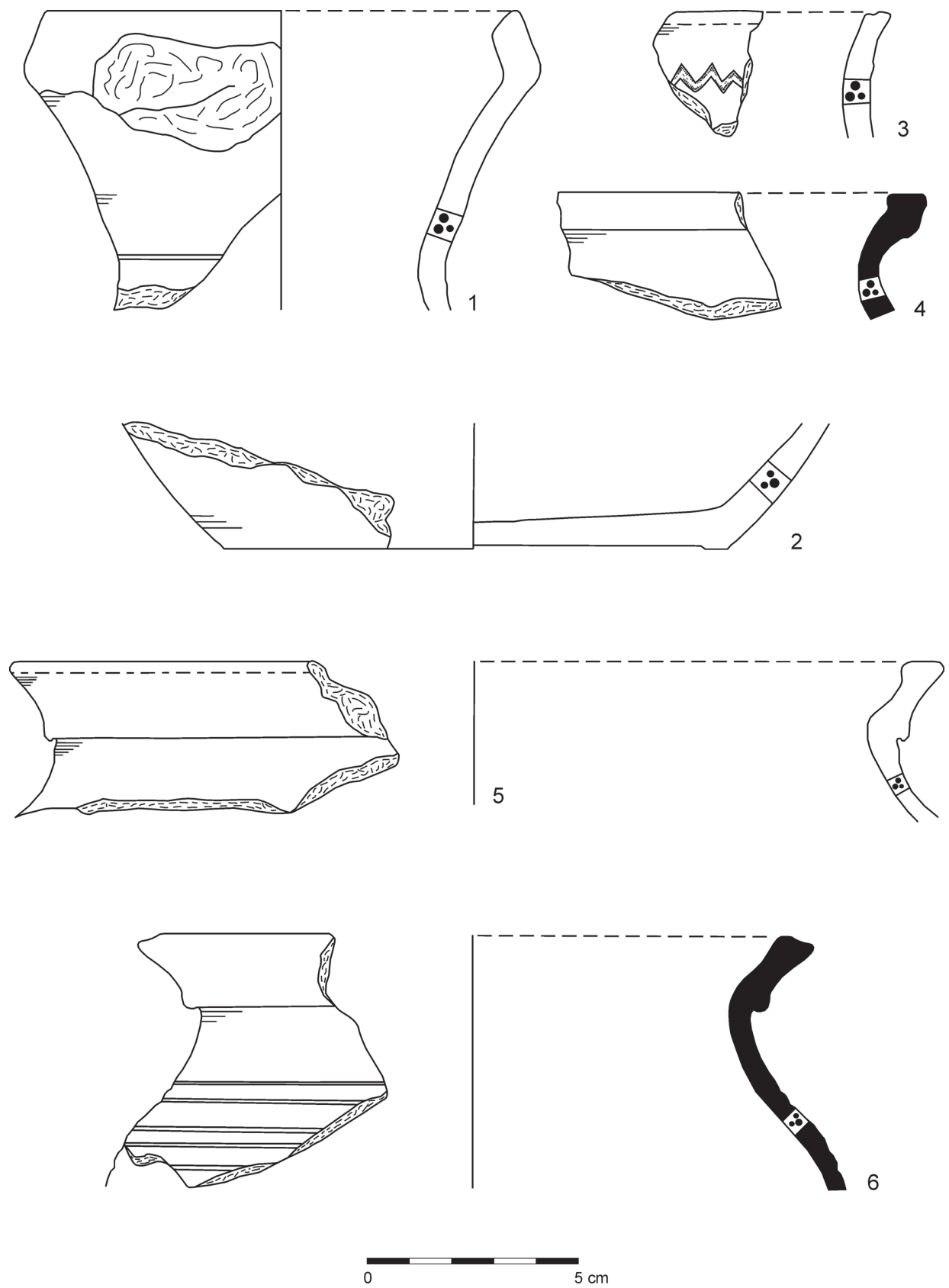

Ryc. 7. Gieczno, gm. Zgierz, pow. zgierski, woj. łódzkie. Wybór ceramiki naczyniowej grupy technologicznej D/A. 1-2) wykop 1, od. a, j.s. 1; 3-6) wykop 1, od. a, j.s. 4 (rys. A. Nierychlewska). 

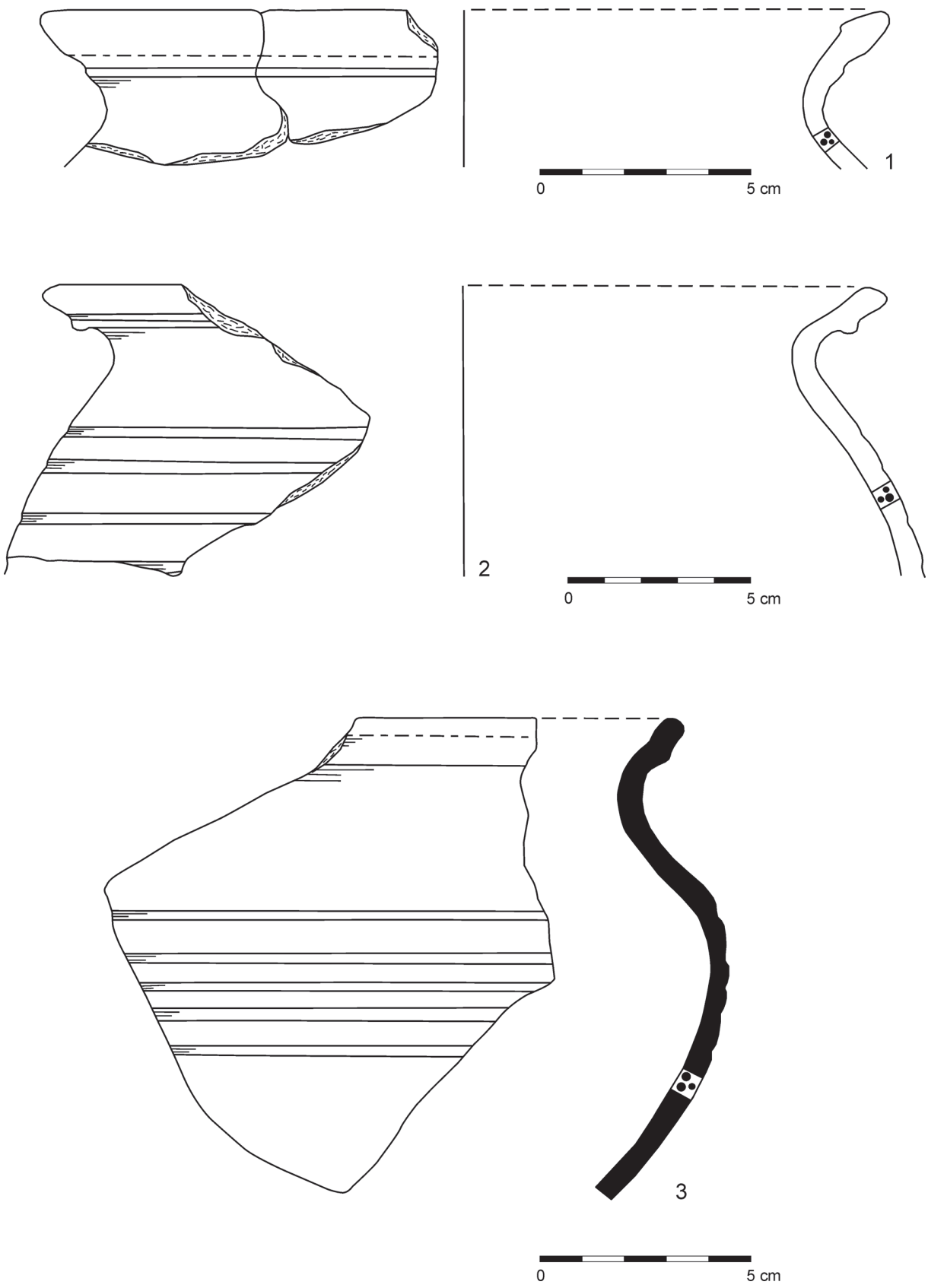

Ryc. 8. Gieczno, gm. Zgierz, pow. zgierski, woj. łódzkie. Wybór ceramiki naczyniowej grupy technologicznej D/A. 1) wykop 1, od. a, j.s. 4; 2) wykop 1, od. a, j.s. 53; 3) wykop 1, od. c, j.s. 30 (rys. A. Nierychlewska). 
miast garnków podtypu G.IIa (ryc. 7: 4; 9: 1) oraz typów G.III i G.IV (ryc. 7: 3) zidentyfikowano jedynie pojedyncze egzemplarze. Średnice garnków wynosiły od 16 do $23 \mathrm{~cm}$, dzbana $12 \mathrm{~cm}$.

\section{Grupa B/A}

Nielicznie reprezentowana, objęła bowiem tylko 6,79\% ogółu materiałów (100 ułamków) (tabela 1, wykres 1). Zaliczone zostały do niej fragmenty naczyń wypalonych w słabo zaawansowanej atmosferze redukcyjnej, nadającej ich ściankom niejednolitą barwę - beżowo lub kremowo-szarą. Najczęściej różne części tego samego naczynia nosiły zarówno cechy wypału redukcyjnego, jak i utleniającego. Przypuszczalnie stanowiły one nieudane próby wypału redukcyjnego. Do produkcji wyrobów używano gliny schudzanej najczęściej domieszką piasku drobno i średnioziarnistego z przewagą frakcji średnioziarnistej, dodawaną w ilości średniej (76\%) oraz piasku drobno i średnioziarnistego z przewagą frakcji drobnoziarnistej, użytą w ilości małej (11\%). Sporadycznie stosowano domieszkę piasku drobno i średnioziarnistego z dodatkiem gruboziarnistego $\mathrm{w}$ ilości średniej (8\%) oraz piasku średnio i drobnoziarnistego z tłuczniem (5\%). Wszystkie naczynia posiadały wielobarwne przełamy. Ponad $90 \%$ wyrobów nosiło ślady użytkowania w postaci okopceń ścianek.

W grupie dominowały fragmenty pochodzące z części środkowych naczyń (74 ułamki). W znacznie mniejszym stopniu reprezentowane były krawędzie i szyje - 7 fragmentów oraz dna i części przydenne - 19 ułamków. Dna ukształtowane były płasko, trzy z nich posiadały pierścienie dookolne. Na 6 fragmentach zachowały się ślady podsypki z piasku. Nie udało się dokonać pomiaru średnicy żadnego z nich. Wyroby były bardzo oszczędnie zdobione. Na zaledwie 17 fragmentach odnotowano ornament żłobków dookolnych.

Wśród form wyróżniono jedynie garnki podtypów G.Ia, G.Ib i G.IIa (ryc. 10: $1-2)$, z których najbardziej popularny był podtyp G.Ib. Zmierzone średnice naczyń wynosiły 18 i $20 \mathrm{~cm}$.

\section{Grupa B}

Była najliczniej reprezentowana w zbiorze ceramiki, objęła bowiem 868 fragmentów, co stanowiło 58,97\% ogółu (tabela 1, wykres 1). Masę garncarską stosowaną do produkcji naczyń schudzano głównie piaskiem drobno i średnioziarnistym z przewagą frakcji średnioziarnistej, dodawanym w ilości średniej $(69,8 \%)$ oraz piaskiem drobno i średnioziarnistym z przewagą frakcji drobnoziarnistej, w ilości małej (23\%). Rzadziej używano piasku drobno i średnioziarnistego z dodatkiem gruboziarnistego w ilości średniej (5,3\%) lub piasku drobnoziarnistego w ilości średniej $(0,9 \%)$ lub małej $(0,2 \%)$. Sporadycznie występowała domieszka piasku średnio i drobnoziarnistego z tłuczniem $(0,3 \%)$. 

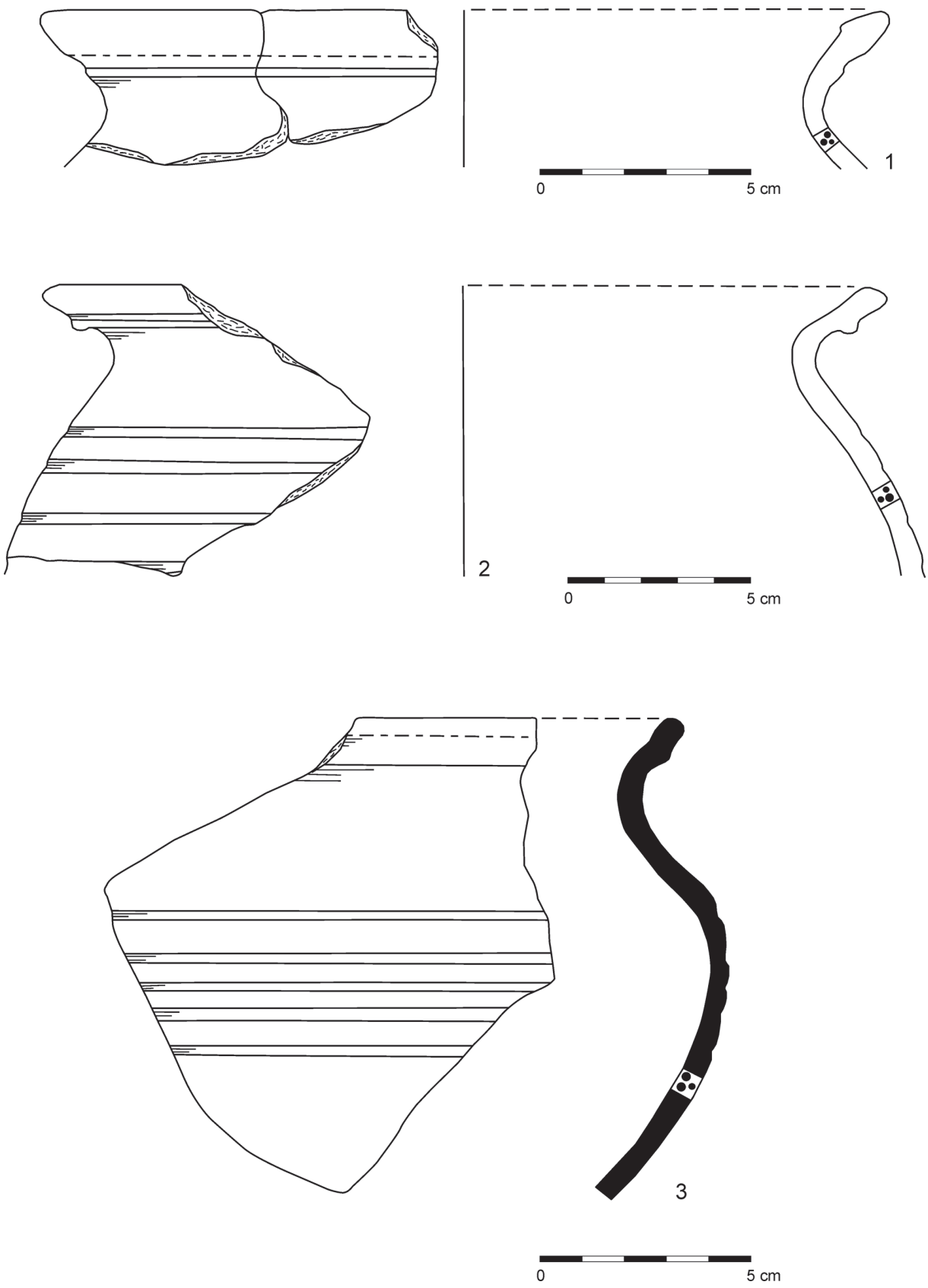

Ryc. 9. Gieczno, gm. Zgierz, pow. zgierski, woj. łódzkie. Wybór ceramiki naczyniowej grupy technologicznej D/A. 1) wykop 2, j.s. 13; 2-3) wykop 2, j.s. 15; 4) wykop 2, j.s. 16 (rys. A. Nierychlewska). 

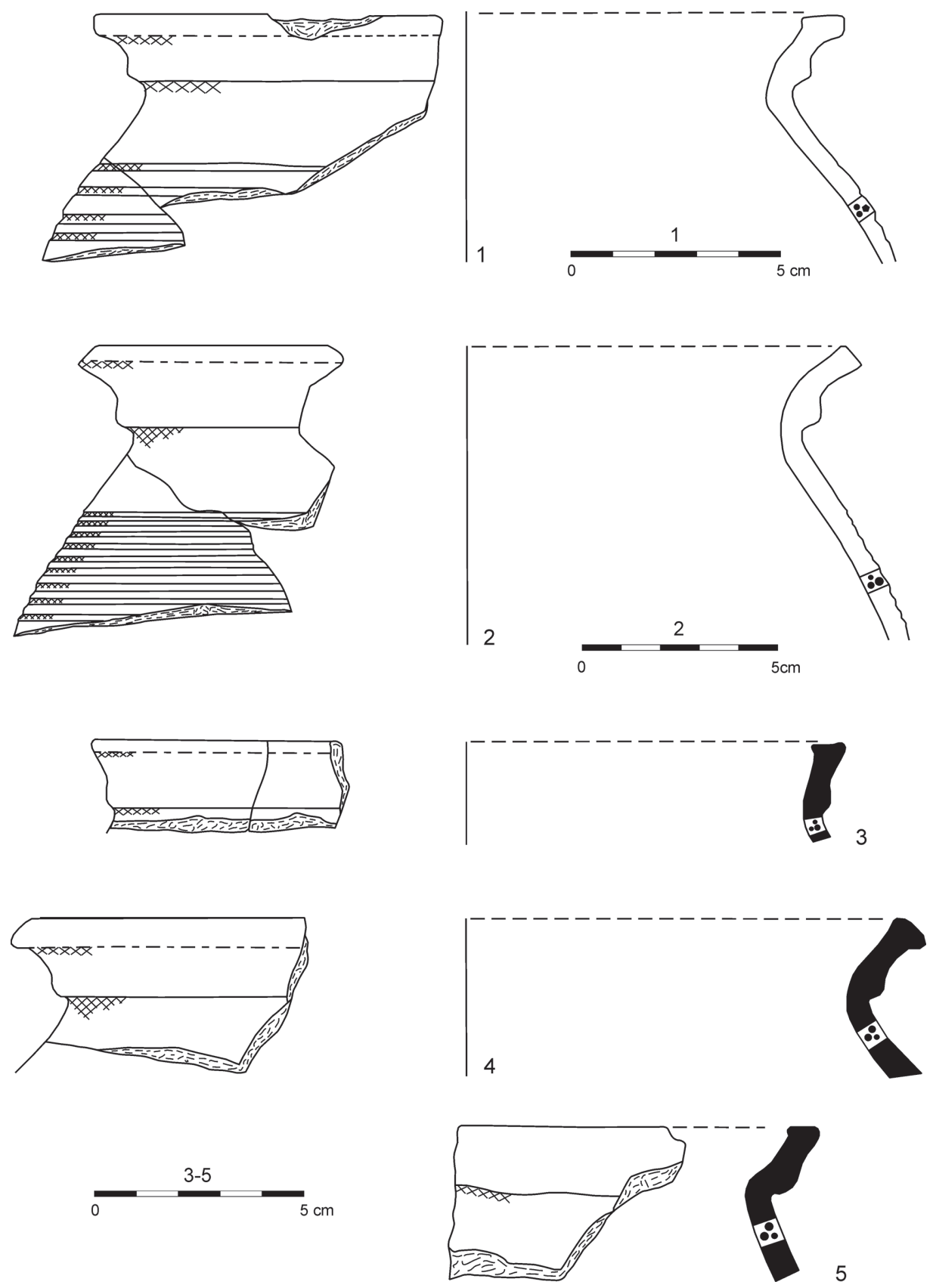

Ryc. 10. Gieczno, gm. Zgierz, pow. zgierski, woj. łódzkie. Wybór ceramiki naczyniowej grupy technologicznej B/A: 1) wykop 1, od. c, j.s. 43; 2) wykop 1, od. c, j.s. 43 i grupy technologicznej B: 3-5) wykop 1, od. a, j.s. 4 (rys. A. Nierychlewska). 
Wypał odbywał się w atmosferze redukcyjnej, nadającej ściankom wyrobów barwę ciemno lub jasnoszarą. Naczynia wypalone były dosyć słabo, znaczna ich część $(46,1 \%)$ posiadała różnobarwne przełamy. Ponad $80 \%$ fragmentów nosiło ślady okopceń świadczących o ich użytkowaniu.

Zbiór ceramiki redukcyjnej obejmuje głównie fragmenty pochodzące z części środkowych naczyń (711 fragmentów). Mniej licznie reprezentowane były krawędzie i szyje (78 fragmentów) oraz dna i części przydenne (72 ułamki). Sporadycznie rejestrowano pokrywki (6 fragmentów) oraz ułamki taśmowatych uch dzbanów. Dna naczyń były płaskie lub niekiedy lekko wklęsłe, na 29 ułamkach zachowały się ślady podsypki, głównie z piasku (23 fragmenty), rzadziej surowców organicznych, na dwóch ślady podważania naczynia od tarczy koła. $\mathrm{Na}$ jednym fragmencie widoczny był odcisk osi koła garncarskiego, na kolejnych trzech odciski drewnianej faktury koła. Jedno dno posiadało pierścień dookolny, dwa inne były sygnowane znakami garncarskim w postaci krzyża równoramiennego (ryc. 11: 3; 13: 2). Zmierzona średnica jednego dna wynosiła 10,4 cm (ryc. 13: 5). Ornamentyka naczyń była najbardziej zróżnicowana ze wszystkich grup technologicznych. Zdobienie odnotowano na ponad 30\% wyrobów (276 fragmentów). Dominowały jednowątkowe motywy składające się głównie z płytszych lub głębszych żłobków dookolnych (265 ułamków, 96\% ornamentowanych), rzadziej rejestrowano: wyświecanie i wygładzanie powierzchni (4 fragmenty), odciskaną „kratkę” (2 ułamki), nacięcia ukośne oraz odciskaną ,jodełkę" (po jednym fragmencie). Wśród motywów dwuwątkowych odnotowano na pojedynczych fragmentach połączenie żłobków dookolnych z nacięciami ukośnymi oraz ,jodełki” z „kratką". Jedna krawędź była zdobiona odciskami dołków palcowych.

Wśród form naczyń dominowały, jak w przypadku wyżej opisanych grup, garnki należące do typów G.I i G.II. Zidentyfikowano także pojedyncze fragmenty dzbanów typu D.I (ryc. 13: 3), pokrywek oraz mniejszych naczyń garnuszków i dzbanków. Wśród garnków najbardziej popularny był wyraźnie dominujący podtyp G.Ib (ryc. 10: 3-5; 11:2, 5; 12: 2, 4; 13: 1, 4), rzadziej rejestrowano podtypy G.Ia (ryc. 11: 4) i G.Id (ryc. 11: 1; 12: 1, 3), natomiast sporadycznie G.IIa i G.IIb. Średnice garnków zawierały się w przedziale 15-22 cm.

\section{Grupa C}

Nielicznie reprezentowana w zbiorze ceramiki grupa. Zaliczonych do niej zostało zaledwie 25 fragmentów (1,7\% ogółu - tabela 1, wykres 1$)$ cienkościennych, starannie wykonanych naczyń. Masę garncarską stosowaną do produkcji wyrobów schudzano głównie piaskiem drobnoziarnistym dodawanym w ilości średniej (88\%), rzadziej stosowano piasek drobnoziarnisty w ilości małej (12\%). Wypał naczyń odbywał się w atmosferze redukcyjnej, nadającej ściankom wyrobów barwę ciemnostalową lub ciemnoszarą. Przeważały przełamy 

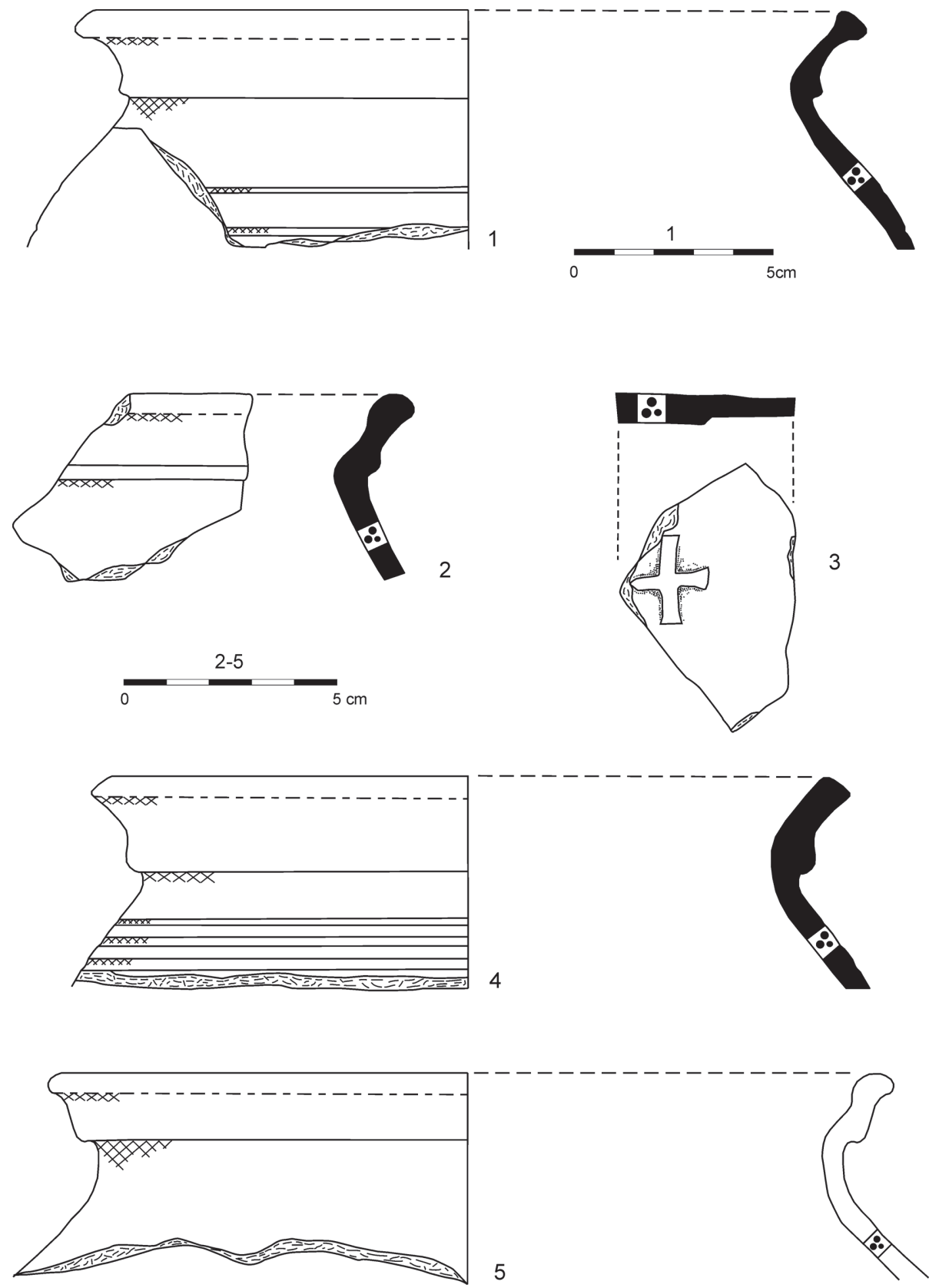

Ryc. 11. Gieczno, gm. Zgierz, pow. zgierski, woj. łódzkie. Wybór ceramiki naczyniowej grupy technologicznej B. 1) wykop 1, od. a, j.s. 31; 2) wykop 1, od. a, j.s. 4; 3) wykop 1, od. c, j.s. 1; 4) wykop 1, od. c, j.s. 30; 5) wykop 1, od. c, dolny poziom fosy, j.s. 73 (rys. A. Nierychlewska). 

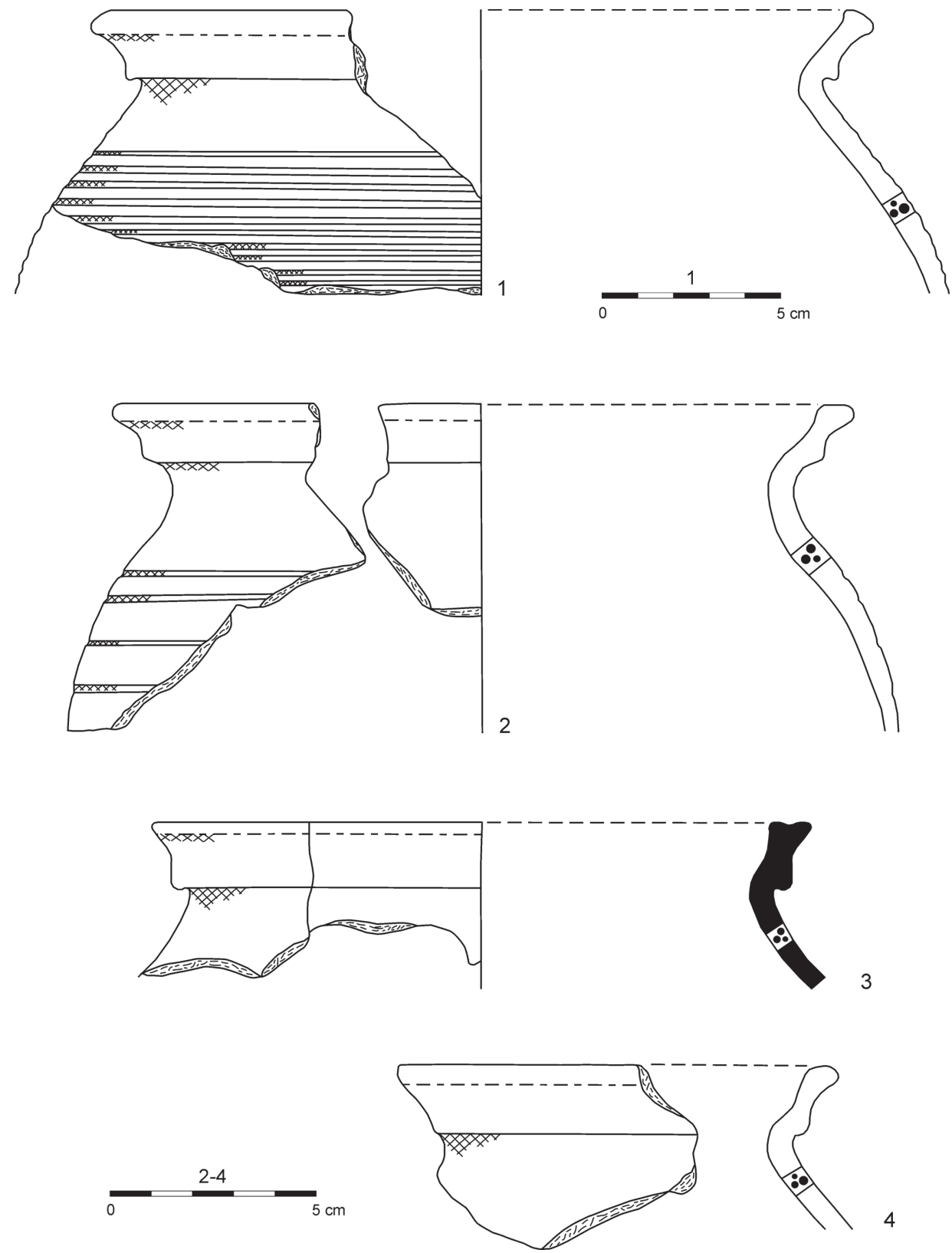

Ryc. 12. Gieczno, gm. Zgierz, pow. zgierski, woj. łódzkie. Wybór ceramiki naczyniowej grupy technologicznej B. 1-2) wykop 1, od. c, dolny poziom fosy; 3-4) wykop 1, od. c, spąg fosy (rys. A. Nierychlewska). 

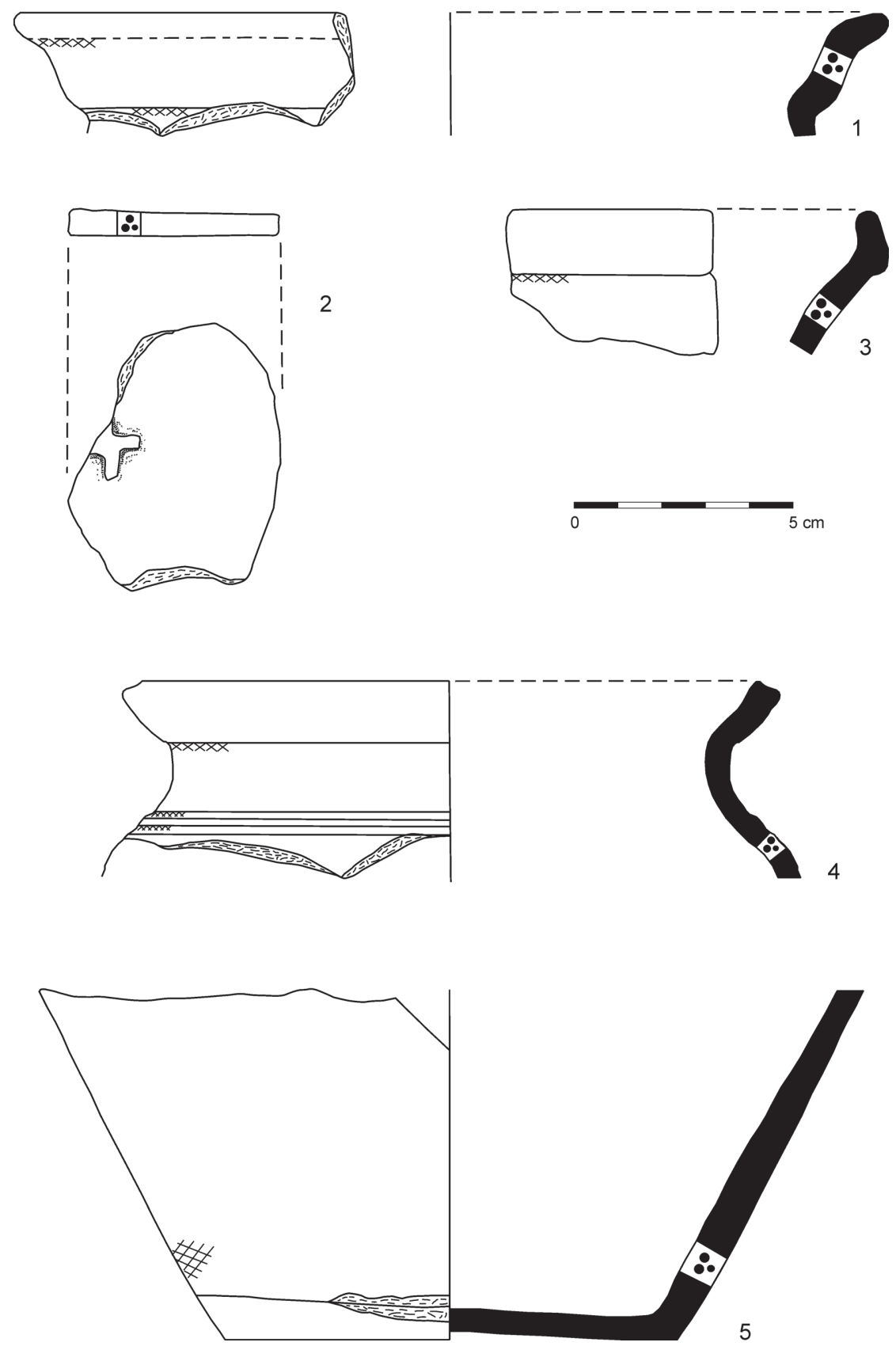

Ryc. 13. Gieczno, gm. Zgierz, pow. zgierski, woj. łódzkie. Wybór ceramiki naczyniowej grupy technologicznej B. 1-2) wykop 2, j.s. 13; 3-5) wykop 2, j.s. 15 (rys. A. Nierychlewska). 
różnobarwne (56\% ułamków), jednobarwne stanowiły 44\%. Ścianki naczyń nie nosiły śladów okopceń i przywar.

$\mathrm{W}$ grupie $\mathrm{C}$ dominowały niewielkie fragmenty pochodzące $\mathrm{z}$ części środkowych naczyń (20 ułamków). Sporadycznie rejestrowano krawędzie i szyje (3 fragmenty) oraz dna i ucha (po jednym ułamku). Jedyne zachowane dno ukształtowane było płasko, nie były na nim widoczne żadne ślady związane z produkcją naczynia. Fragment ten był zbyt mały aby dokonać pomiaru średnicy. Wszystkie fragmenty były ornamentowane, głównie poprzez wyświecanie powierzchni wyrobu (19 ułamków), rzadziej jej wygładzanie (4 fragmenty). Na 2 ułamkach zarejestrowano połączenie wyświecania powierzchni ze żłobkami dookolnymi.

Wśród form naczyń wyróżniono jedynie fragment wylewu niewielkiego dzbanka oraz miseczki typu M.I.

\section{Grupa D}

Do ceramiki naczyniowej wypalonej w atmosferze utleniającej zaliczonych zostało zaledwie 9 fragmentów, co stanowiło $0,6 \%$ zbioru (tabela 1, wykres 1 ). W grupie tej wydzielone zostały dwie podgrupy - Dc i Dk. Do pierwszej, obejmującej wyroby z glin żelazistych, zakwalifikowano 4, a do drugiej grupującej naczynia z glin jasnych, kremowych - 5 fragmentów. Ze względu na niewielką liczbę ułamków obie podgrupy zostaną omówione wspólnie.

Do produkcji naczyń używano masy garncarskiej schudzanej najczęściej domieszką piasku drobno i średnioziarnistego z przewagą frakcji drobnoziarnistej w ilości małej (78\%), rzadziej piasku drobno i średnioziarnistego z przewagą frakcji średnioziarnistej, dodawanego w ilości średniej (12\%). Czerepy naczyń uzyskiwały po wypaleniu barwę ceglastą, pomarańczowo-ceglastą (podgrupa Dc) i kremową (podgrupa $\mathrm{Db}$ ), a 88,9\% wyrobów posiadało wielobarwne przełamy. Blisko połowa naczyń nosiła ślady użytkowania w postaci okopceń.

W grupie tej ilościowo dominowały fragmenty należące do środkowych części naczyń (6 ułamków). Krawędzie obejmowały 2 ułamki, dna zaledwie jeden. Zachowany fragment dna ukształtowany był prosto, ze stopką. Był za mały aby dokonać pomiaru średnicy naczynia. Zaledwie na trzech fragmentach wyrobów stwierdzono ornament w postaci płytkich żłobków dookolnych.

Wśród pozyskanych ułamków udało się rozpoznać jedynie fragmenty należące do garnków podtypu G.Ib. Były one zbyt małe aby dokonać pomiaru średnicy naczynia.

\section{Próba OKREŚLENIA CHRONOLOGI ZBIORU CERAMIKI NACZYNIOWEJ}

W zbiorze ceramiki późnośredniowiecznej z gródka w Giecznie wyraźnie dominowały naczynia wypalone $\mathrm{w}$ atmosferze redukcyjnej, zaliczone do grup 
technologicznych B i C (łącznie 62,1\%), charakterystyczne dla rozwiniętych faz późnego średniowiecza (II okres rozwoju garncarstwa późnośredniowiecznego według Kruppego 1981: 49 i nn.). Znaczny udział miały też wyroby wypalone W słabo zaawansowanej atmosferze utleniającej lub redukcyjnej, zaklasyfikowane do grup technologicznych D/A i B/A (łącznie 35,1\%). Zaledwie niewielki odsetek stanowily natomiast fragmenty naczyń nawiązujących w technice wykonania i składzie masy ceramicznej do tradycji wczesnośredniowiecznych (grupa technologiczna A - 3,46\%). Wyroby grup A, D/A i B/A występują najliczniej na stanowiskach datowanych na przełom wczesnego i późnego średniowiecza oraz początki późnego średniowiecza (I okres rozwoju garncarstwa późnośredniowiecznego według Kruppego 1981: 49 i nn). Równie nieznaczny był udział naczyń wypalonych w zaawansowanej atmosferze utleniającej (grupa technologiczna $\mathrm{D}-0,6 \%$ ), pojawiających się w większej ilości na stanowiskach o chronologii wiązanej ze schyłkiem późnego średniowiecza i czasami wczesnonowożytnymi. Ceramika ta wykonywana była techniką taśmowo-ślizgową, następnie całkowicie obtaczana na kole garncarskim. W większości przypadków charakteryzował ją słaby wypał, różnobarwne przełamy i niejednolita barwa czerepów.

Na dwóch dnach grupy technologicznej B dało się zauważyć znaki garncarskie w postaci krzyża równoramiennego. Na kolejnym dnie krzyż zachowany był fragmentarycznie. Analogiczne znaki znane są m.in. z materiałów z Pęcławic, pow. łęczycki (Dziubek 2011: 92, ryc. 37), Siedlątkowa, pow. poddębicki (Kamińska 1968: 49), Orłowa nad Bzurą (Kajzer 1989-1990: 274) czy Strzelna (Sulkowska-Tuszyńska 1997: 46, tabela 14).

Ceramika redukcyjna, dominująca w zbiorze z Gieczna, w różnych ośrodkach w Polsce zaczęła się pojawiać od przełomu XII i XIII w. oraz w pierwszej połowie XIII w. Dla przykładu na grodzie w Szczecinie pojedyncze egzemplarze znajdywane były w warstwach wiązanych z przełomem XII i XIII w. oraz początkami wieku XIII. Masowo „siwaki” występują w nawarstwieniach z drugiej połowy XIII w. (Łosiński, Rogosz 1986: 52-53), w Stargardzie pojawiają się w poziomach ze schyłku drugiej ćwierci - początków trzeciej ćwierci XIII w. (Rogosz 1986: 121), w Trzebiatowie około połowy XIII w. (Rogosz 1981: 114, 119), podobnie w Kołobrzegu (Rębkowski 2007: 210). W Gdańsku na terenach miasta lokacyjnego w warstwach z drugiej połowy XIII - początków wieku XIV udział naczyń wypalonych w atmosferze redukcyjnej sięgał 60-70\%. Mniej popularne były one na terenie dawnego podgrodzia, gdzie ich udział do schyłku pierwszej ćwierci XIV w. nie przekraczał kilku procent (Leciejewicz 1962: 121; Nawrolski 1978: 159). W podobnym przedziale czasowym, od drugiej ćwierci XIII w., pojawiają się we Wrocławiu (Kaźmierczyk 1970: 286), czy w Poznaniu od około połowy XIII w. (Dębska-Luty 1972: 165, tabl. A). Bardzo wysoki był udział naczyń redukcyjnych w materiałach z klasz- 
toru oo. Franciszkanów w Inowrocławiu, gdzie pierwsze egzemplarze tychże wyrobów odnotowano w nawarstwieniach z połowy XIII w., natomiast w warstwach z drugiej połowy XIII - drugiej-trzeciej ćwierci XIV w. ich udział sięgał 95,6\% (Bednarczyk 1979: 69, 71, tabela 6, 8). Również w Kruszwicy ceramika redukcyjna poświadczona była $\mathrm{w}$ nawarstwieniach wiązanych $\mathrm{z}$ drugą połową XIII w. w ilości $24,05 \%$, a w warstwach z pierwszej połowy XIV w. jej udział wynosił już 58,4\% (Dzieduszycki 1982, tabela 3, 10). W pobliskim Strzelnie w materiałach $\mathrm{z}$ klasztoru norbertanek w fazie II datowanej na drugą-trzecią ćwierć XIII - czwartą ćwierć XIV w. zarejestrowano 23,8\% naczyń redukcyjnych (Sulkowska-Tuszyńska 1997: 49). Jedynie wśród materiałów ceramicznych z zamków w Brześciu Kujawskim i Raciążku naczynia redukcyjne notowane są nieco później, dopiero od drugiej ćwierci XIV w. (Kajzer 1990: 214; Kapusta 1997: 154-160), podobnie z zespołu dominikańskiego w Brześciu Kujawskim (Andrzejewska, Kajzer 1995, tabela 11, 12). Zbieżne obserwacje poczyniono podczas analizy zbioru ceramiki naczyniowej z osady produkcyjnej w Bogusławicach koło Wolborza, datowanego na XIV - przełom XIV/XV w., gdzie udział naczyń wypalonych $\mathrm{w}$ atmosferze redukcyjnej osiągnął zaledwie $0,33 \%$. Przeważały natomiast wyraźnie wyroby wypalane w słabo zaawansowanej atmosferze utleniającej (Chmielowska, Góra 2009: 159). Podobna sytuacja miała miejsce wśród datowanych na połowę i drugą połowę XIV w. materiałów z gródka w Siedlątkowie, gdzie ceramika wypalona w słabo zaawansowanej atmosferze utleniającej stanowiła 90\% ogółu zbioru, natomiast redukcyjna obejmowała zaledwie 10\% naczyń (Kamińska 1968: 49-51).

Z bliższych Giecznu stanowisk ceramika redukcyjna na osadzie w Pęcławicach, pow. łęczycki, woj. łódzkie odnotowana została w większej ilości (powyżej 40\%) w materiałach datowanych od drugiej połowy XIV w. (Dziubek 2011: 77, wykres 6).

Można zatem przyjąć drugą połowę XIII w. za czas pojawienia się ceramiki redukcyjnej w większości znaczących ośrodków w Polsce. Na przestrzeni XIV w., naczynia wypalane w atmosferze redukcyjnej upowszechniają się, wyraźnie dominując w materiałach z XV i pierwszej połowy XVI w. (por. dane dla Inowrocławia, Raciążka, Strzelna, Brześcia Kujawskiego czy Pęcławic: Bednarczyk 1979, tabela 6; Kajzer 1990: 214-222; Sulkowska-Tuszyńska 1997: 61-62; Kapusta 1997: 155-159; Dziubek 2011: 77, wykres 6).

Natomiast naczynia wypalone $\mathrm{w}$ zaawansowanej atmosferze utleniającej notowane są w materiałach późnośredniowiecznych od końca XIV w. w Strzelnie (Sulkowska-Tuszyńska, 1997: 62-63), na zamku w Raciążku, sporadycznie w warstwach datowanych od wieku XV (Kajzer 1990: 214-221). Wraz z ceramiką grupy technologicznej D pojawiają się wyroby szkliwione, angobowane czy malowane grup technologicznych $\mathrm{E}$ i F, te ostatnie nienotowane w Giecznie. 
Asortyment naczyń z gródka w Giecznie był ogólnie mało zróżnicowany. Dominowały garnki, rzadziej udawało się zidentyfikować fragmenty należące do dzbanów, a sporadycznie do mniejszych naczyń - garnuszków i dzbanków, miseczek czy pokrywek. Niewielki też udział miała ceramika „stołowa” grupy technologicznej C. Zauważalna jest zbieżność typów wyrobów wypalanych w atmosferze utleniającej i redukcyjnej. W grupie technologicznej A odnotowano jedynie garnki podtypów G.Id i G.IIb. Pierwszy obejmował formy o silniej profilowanych, taśmowatych krawędziach wylewów zaopatrzonych we wrąb i okap, drugi wyroby o nieprofilowanej krawędzi wylewu, bez wrębu. W grupach technologicznych $\mathrm{D} / \mathrm{A}$ i B/A oprócz dominujących garnków, wyróżniono także nieliczne fragmenty dzbanów typu D.I, miseczek typu M.I oraz pokrywek. Wśród garnków grup D/A i B/A najliczniej występowały formy typu G.I - garnków z taśmowatą, słabiej lub silniej profilowaną krawędzią wylewu zaopatrzoną w okap i wrąb, tylko wrąb lub tylko okap. Wśród nich najbardziej popularny był podtyp G.Ib z silniej lub słabiej zaznaczonym wrębem, bez okapu. Mniej licznie reprezentowane były wyroby zaliczone do podtypów G.Ia, G.Ic, G.Id oraz G.IIa z nieprofilowaną krawędzią wylewu. Pojedyncze egzemplarze należały do form z lekko profilowaną, niepogrubioną krawędzią wylewu ze słabo zaznaczonym wrębem (typ G.III) oraz do naczyń z cylindryczną szyją (typ G.IV). Garnki typów G.III i G.IV nawiązywały pod względem form do naczyń wczesnośredniowiecznych, natomiast wyroby typów G.I i G.II do późnośredniowiecznych. Wśród ornamentów naczyń grup technologicznych A, D/A i B/A najbardziej popularne były jednowątkowe motywy żłobków dookolnych, rzadziej rytej linii falistej i nacięć ukośnych oraz dwuwątkowe motywy żłobków dookolnych połączonych z nacięciami ukośnymi.

W grupach technologicznych B i C zanikają garnki z cylindryczną szyją (typ G.IV) oraz garnki o słabo profilowanej, niepogrubionej krawędzi wylewu (typ G.III). Nadal największą popularnością cieszyły się garnki podtypu G.Ib, notowano także w większej ilości naczynia podtypów G.Ia i G.Id, natomiast sporadycznie należące do typu G.II o nieprofilowanych krawędziach wylewu. W grupie tej wystąpiły również pojedyncze dzbany typu D.I, pokrywki, miseczki typu M.I oraz mniejsze naczynia garnuszki i dzbanki. Nieznacznie poszerzył się zestaw motywów zdobniczych. Oprócz nadal popularnych żłobków dookolnych pojawiły się nieliczne naczynia ornamentowane odciskaną „kratką" i ,jodełką", zanikła natomiast linia falista. Obserwowano także naczynia o wyświecanych i wygładzanych powierzchniach. Analogiczne wyroby notowane były w zbiorach ze Strzelna $\mathrm{z}$ fazy wiązanej z drugą-trzecią ćwiercią XIII - czwartą ćwiercią XIV w. (Sulkowska-Tuszyńska 1997: 46) oraz w Inowrocławiu, gdzie ten sposób zdobienia obserwowano od drugiej-trzeciej ćwierci XIV w. (Bednarczyk 1979: 98, 102). W Warszawie zdobione w ten sposób naczynia pojawiają się w pierwszej połowie XIV w., a upowszechniają 
się w drugiej jego połowie i w wieku XV (Kruppe 1961: 70; 1967: 191-192), podobną tendencję można zaobserwować na innych stanowiskach (Kruppe 1981, tabl. 41-44, 46, 73, 74).

Analogiczne wyroby notowane były na stanowiskach położonych w pobliżu Gieczna. Wśród materiałów z Pęcławic, gm. Piątek datowanych od drugiej połowy XIII po pierwszą połowę XIV w. licznie obserwowane były naczynia z cylindryczną szyją oraz garnki z niepogrubionymi, słabo profilowanymi krawędziami wylewów zaopatrzonymi we wręby (odpowiedniki typów G.III i G.IV z Gieczna), natomiast w grupie o chronologii od XIV po pierwszą połowę XV w. znajdowały się garnki o taśmowatych, profilowanych krawędziach wylewów (odpowiedniki typu G.I). Udział ceramiki redukcyjnej w okresie od drugiej połowy XIV po pierwszą połowę XV w. wynosił $44 \%$, zaś w datowanym na drugą połowę XV w. już 63\% (Dziubek 2011: 77, ryc. 76-81, wykres 6). Wysoki, sięgający blisko 64\% udział naczyń redukcyjnych zarejestrowano także wśród łączonych z drugą połową XIV w. materiałów z gródka stożkowatego w Dmosinie, pow. brzeziński. W zbiorze tym odnotowano też znaczną ilość ceramiki (niestety określenie udziału procentowego jest niemożliwe gdyż została ona $\mathrm{w}$ tabeli zbiorczej połączona $\mathrm{z}$ naczyniami wypalonymi $\mathrm{w}$ atmosferze utleniającej) wypalonej niestarannie w atmosferze redukcyjnej o różnobarwnych przełamach i powierzchniach naczyń, odpowiadającej grupie B/A z Gieczna (Horbacz, Lechowicz 1982: 280-282). Natomiast w materiałach z dworu w Orłowie nad Bzurą datowanych od przełomu XIII/XIV w. po pierwszą połowę XV w. wyraźnie dominowały naczynia nawiązujące $\mathrm{w}$ technice produkcji do tradycji wczesnośredniowiecznych oraz wyroby noszące cechy prób wypału w atmosferze redukcyjnej grup technologicznych A i A/B (łącznie $87,05 \%$ - przy czym ich udziały wynosiły po 50\%). Warto nadmienić, że w zbiorze ceramiki grupy A około $10 \%$ stanowiły naczynia lepiej wypalone o barwie pomarańczowo-ceglastej, które mogły odpowiadać grupie D/A z Gieczna. Udział ceramiki grupy technologicznej B wynosił 12,71\%. W materiałach z Gieczna nie wystąpiły natomiast wyroby szkliwione (grupa E) oraz wykonane $\mathrm{z}$ glin kaolinitowych, niekiedy zdobione czerwoną malaturą (grupa D), nielicznie reprezentowane w materiałach z Orłowa (łącznie zaledwie 0,24\% ogółu). Wśród form naczyń z Orłowa wyróżniono m.in. najliczniej reprezentowane garnki o taśmowatych krawędziach wylewu, silniej lub słabiej profilowanych, popularne również wśród materiałów z Gieczna (typ G.I), garnki o pogrubionych, zaokrąglonych krawędziach wylewu, najczęściej z wrębem (typ G.II z Gieczna). Zarejestrowano także nieliczne ułamki garnków z cylindryczną szyją (odpowiednik typu G.IV), dzbany, garnuszki i pokrywki (Kajzer 1989-1990: 265-280, ryc. 7, 8, 10, 11). Podobne do typu G.I z Gieczna formy naczyń pochodziły również z gródka w Siedlątkowie. Wśród tychże materiałów wyróżniono dwie grupy ceramiki wypalonej w słabo zaawansowanej atmosferze utleniającej - do pierwszej zaliczono wyroby grubościenne, brunat- 
noszare o grubej domieszce (około 50\%), do drugiej naczynia wykonane z masy garncarskiej o drobniejszej domieszce, lepiej wypalone (około 40\%) (Kamińska 1968: tabl. 7), mogące odpowiadać grupie D/A z Gieczna.

Podsumowując, biorąc pod uwagę znaczny udział naczyń wypalonych $\mathrm{w}$ atmosferze redukcyjnej oraz słabo zaawansowanej atmosferze utleniającej i redukcyjnej, przy jednoczesnej nieznacznej ilości wyrobów wypalonych w zaawansowanej atmosferze utleniającej, chronologię zespołu naczyń późnośredniowiecznych z Gieczna można łączyć z XIV, pierwszą połową XV w.

$\mathrm{Na}$ początek późnego średniowiecza wskazuje również udział naczyń nawiązujących technologią wykonania do wyrobów wczesnośredniowiecznych, obecność garnków z cylindryczną szyją występujących w zespołach naczyń wczesnośredniowiecznych oraz pochodzących z początku późnego średniowiecza, a zanikających w materiałach datowanych od 2 poł. XIV w., czy obecność den sygnowanych znakami garncarskimi. Na rozwinięte fazy późnego średniowiecza wskazują natomiast: dominujący w zbiorze udział ceramiki redukcyjnej, mimo, że była ona wykonana i wypalona mało starannie, licznie reprezentowane formy garnków z taśmowatymi, profilowanymi wylewami (typ G.I), garnków z zaokrągloną krawędzią wylewu i zaakcentowanym wrębem (typ G.II) oraz zdobienia naczyń poprzez wyświecanie i wygładzanie ich powierzchni.

\section{NieZALEŻNE ANALIZY CHRONOLOGICZNE}

Szczegółowe rozważania na temat wyników analiz dendrochronologicznych i radiowęglowych przeprowadzonych dla Gieczna zostaną opublikowane w innym miejscu. Tutaj zaprezentowane zostaną wyłącznie informacje niezbędne w kontekście ustalenia chronologii zbioru ceramicznego.

Datowaniu dendrochronologicznemu w Laboratorium Datowań Bezwzględnych w Cianowicach koło Skały poddano 4 próbki pochodzące z półokrąglaków palisady. Analiza ujawniła, że trzy próbki (dęby) ścięto w tym samym roku, jedną zaś 2 lata później (także dąb). Niestety porównanie ich do znanych skal dendrochronologicznych, przygotowanych dla obszaru Polski, nie pozwoliło na określenie dat bezwzględnych. W związku z tym wykonano na jednej z próbek analizę radiowęglową (numer laboratoryjny MKL-2882), która dostarczyła datę konwencjonalną $650 \pm 40 \mathrm{BP}$. Po kalibracji w programie OxCal 4.2.3 (Bronk, Ramsey 2013) za pomocą krzywej atmosferycznej (Reimer i in. 2013), z prawdopodobieństwem 95,4\% uzyskano przedział dat kalendarzowych 1277-1399 AD. W ramach pierwszego przedziału prawdopodobieństwa $(68,2 \%)$ czytelne są tu dwa zakresy: z ufnością 31,5\% 1286-1316 AD oraz 36,7\%: 1355-1389 AD.

W tym kontekście należy wspomnieć o datowaniu dendrochronologicznym próbki 4, pozyskanej w rejonie pieca w wykopie 2. Dębowy fragment został 
ścięty w $1301 \mathrm{AD}$. Element ten był redeponowany, jednak pośrednio wskazuje na aktywność w początkach XIV w. Może więc sugerować większe prawdopodobieństwo, które łączyć należy z pierwszym z zakresów prawdopodobieństwa radiowęglowego.

Udało się także uzyskać datę „dendro" z drewnianego pala pochodzącego z jamy związanej z fazą II założenia (j.s. 67). Dębowy pal został ścięty w roku 1422 AD.

\section{DysKuSJa}

Dysponując chronologią, o której wnioskować można na podstawie analizy materiału masowego, jakim są fragmenty naczyń ceramicznych, wynikami niezależnych datowań dendrochronologicznych i radiowęglowych oraz źródłami pisanymi, pokusić się możemy o określenie dynamiki przemian i wyróżnienie dwóch faz rozwoju obiektu.

W starszej fazie elementem defensywnym założenia był niewysoki wał, uzupełniony od zewnątrz przez ukośną palisadę z półokrąglaków. Poza palisadą obiekt chroniony był przez szeroką acz płytką, mokrą fosę oraz niski zewnętrzny wał dookolny. Biorąc pod uwagę stosunkowo mizerne rozmiary tych konstrukcji można przypuszczać, że poza funkcjami prestiżowymi, tworzącymi niezbędny symboliczny element drewnianego zamku, ich rolą było przede wszystkim hydrotechniczne zabezpieczenie rezydencji przed wylewami Moszczenicy. Zabudowę tego niewielkiego obiektu obronnego stanowił drewniany budynek o nieznanej konstrukcji ścian, który w pewnym momencie uległ częściowemu spaleniu. Pożar nie strawił wprawdzie wszystkich jego elementów i nie był najpewniej bardzo niszczący, ale mógł stanowić czynnik powodujący decyzję o przebudowie założenia.

Faza młodsza oznaczała modyfikację układu przestrzennego i defensywnego założenia. W miejscu niewielkiego obiektu o charakterze pierścieniowym wzniesiono kopulasty nasyp, nawiązujący do ogólnoeuropejskiego schematu motte (por. Sikora, Kittel 2017), zachowując starszą fosę i zewnętrzny wał w stanie niezmienionym. Na szczycie kopca posadowiono zapewne drewnianą zabudowę.

Najpewniej już od starszej fazy rezydencji towarzyszyło zaplecze pomieszczone na owalnym wyniesieniu, gdzie także czytelne są kolejne, następujące po sobie horyzonty archeologiczne, będące świadectwem zmieniających się koncepcji zagospodarowania tego terenu. Obecność reliktu pieca może wskazywać, że zaplecze to miało charakter gospodarczy. Obecność żużli natomiast sugeruje działalność metalurgiczną, która w kontekście rezydencji o cechach obronnych nie powinna dziwić.

Niezależne określenia chronologii metodą radiowęglową i dendrochronologiczną wskazują na dwa horyzonty czasowe, w których odbywała się tutaj dzia- 
łalność budowlana. Starszy dotyczy generalnie wieku XIV, przy czym rozkład prawdopodobieństwa daty radiowęglowej z palisady wskazuje albo na schyłek XIII i początek XIV w. albo na około trzecią ćwierć XIV w. Biorąc pod uwagę datę z próbki 4, odnoszącą się do roku $1301 \mathrm{AD}$, można sugerować, że owa starsza faza wiąże się z pierwszą ćwiercią XIV w. Młodszy horyzont wyznaczony jest przez datę dendrochronologiczną $1422 \mathrm{AD}$, dokumentującą aktywność budowlaną u schyłku pierwszej ćwierci XV w.

W tym kontekście należy rozpatrywać omówione wyżej cechy technologiczne i analogie dla materiału ceramicznego. Znaczny udział wyrobów wykonanych $\mathrm{w}$ technologii tradycyjnej, nawiązującej do doskonale znanych od wczesnego średniowiecza metod produkcji i sposobów przygotowania surowca oraz wysoce niedoskonałe próby wdrożenia nowej technologii, jaką był wypał redukcyjny, zdają się korelować właśnie z początkami XIV w. w Polsce centralnej. Znajdują one wyraźne analogie w materiałach datowanych na przełom XIII i XIV w. pochodzących z podobnego obiektu obronno-rezydencjonalnego w Orłowie oraz osady w Pęcławicach. Natomiast występowanie doskonalszych technologicznie naczyń redukcyjnych, dominacja tej metody wypału w zbiorze, obecność naczyń o wyświecanej powierzchni oraz niewielka ilość wypalanych W zaawansowanej technologii utleniającej zdaje się dobrze korelować z pierwszą ćwiercią XV w. Warto jeszcze raz podkreślić brak naczyń szkliwionych oraz malowanych rejestrowanych $\mathrm{w}$ zbiorach pochodzących ze schyłkowych faz późnego średniowiecza i początków okresu nowożytnego w Polsce centralnej. Nie stwierdzono także obecności kafli piecowych, tak charakterystycznych dla obiektów rezydencjonalnych z drugiej połowy XV w. i młodszych. Wszystko wskazuje więc na opuszczenie obiektu około połowy XV stulecia.

Jak wyżej wspomniano, w 1369 r. wieś należała do braci Sieciecha i Boguty z rodu Toporczyków, którzy w tym czasie dokonali podziału majątku dóbr Gieczno (Matriculorum... 1915, nr 167). Rezydencja trafiła zapewne do Boguty. Jego dobra, po podziale koncentrowały się właśnie w tym regionie. Zarówno niezależne metody określania chronologii, jak i analiza materiału ceramicznego, wskazują że istniała już ona wówczas od kilkudziesięciu lat, była więc najpewniej wzniesiona przez ich ojca, a może dziada, niestety nie wymienianych przez źródła pisane. Zamieszkiwali oni najpewniej w drewnianym budynku otoczonym dość prostym obwodem obronnym. Nie była to jeszcze rezydencja nawiązująca do schematu motte - dworu na kopcu. Ta powstała dopiero najpewniej w pierwszej ćwierci XV w. w wyniku przekształcenia starszego obiektu. Źródła wskazują, że w końcu XIV w. miejscowość nadal należała do Toporczyków, braci: Aleksandra, stolnika łęczyckiego w latach 1388-1407 (Bieniak, Szymczakowa 1985, nr A 332), Piotra, Żegoty i Nawoja. Żegota zmarł w 1399 lub 1400 r., Aleksander zrezygnował z udziałów w Giecznie na rzecz Nawoja. W pierwszej połowie XV w. na Giecznie dziedziczył Mikołaj, syn Nawoja. 
Zmarł on w 1440 r., możemy więc wykluczyć jego syna Stanisława z listy potencjalnych budowniczych. Wszystko wskazuje, że osobą, która zainicjowała przekształcenie rezydencji w siedzibę typu motte był Nawój lub Mikołaj.

Zadać należy także pytanie, w jaki sposób materiał ceramiczny z gródka odzwierciedla status i horyzonty giecznieńskich Toporczyków? Zaprezentowana wyżej analiza wykazała całkowity brak ,prestiżowych” form naczyń: importowanych lub pochodzących z miejskich warsztatów rzemieślniczych. Odpowiada on raczej prowincjonalnej, wiejskiej wytwórczości, w której jeszcze na początku XIV w., a zapewne nawet dłużej, kontynuowane były dawne techniki produkcji i formy naczyń. Podejmowano również, w większości przypadków niedoskonałe, próby wdrażania nowej technologii, jaką był wypał redukcyjny. W tym miejscu warto zaznaczyć, że naczynia wypalane w zaawansowanej atmosferze redukcyjnej znane były w przodujących ośrodkach miejskich w Polsce centralnej, już od około połowy XIII w. (por. Sikora 2015: 141). Najwyraźniej użytkownicy drewnianej rezydencji albo nie mieli potrzeby zaopatrywania się w technicznie doskonalsze, bardziej prestiżowe produkty, albo też nie pozwalały im na to możliwości finansowe. Dopiero pokolenia użytkujące obiekt w pierwszej połowie XV w. dysponowały asortymentem nieco bardziej odpowiadającym technologicznym i estetycznym (naczynia zdobione przez wyświecanie powierzchni) wymogom epoki.

\section{Podsumowanie}

Mimo niewielkiego zakresu badań udało się w Giecznie rozpoznać kolejny przykład niewielkiej, prywatnej rezydencji w Polsce centralnej. Wpisujemy się w ten sposób w długą i szacowną tradycję badań takich obiektów, sięgającą Gabriela Leńczyka (por. Horbacz 1997) i Janiny Kamińskiej (1953; 1966), a utrwaloną przełomowymi i ważnymi pracami Leszka Kajzera (1972; 1980; 2004) oraz podsumowaną przez Annę Marciniak-Kajzer (2011). Badania w Giecznie, choć nie tak ważne i nie tak przełomowe, są kolejnym elementem uzupełniającym naszą wiedzę na temat tych niewielkich zazwyczaj założeń, szczególnie zaś ich chronologii, struktury przestrzennej, kontekstu krajobrazowego oraz charakterystyki kultury materialnej. W tym ostatnim zakresie postrzeganej przez pryzmat najpopularniejszej kategorii, jaką były produkty ceramiczne. 


\author{
Anna Nierychlewska \\ Łódź \\ e-mail: ankan@op.pl \\ Jerzy Sikora \\ Instytut Archeologii \\ Uniwersytet Łódzki \\ ul. Narutowicza 65 \\ 90-131 Łódź \\ e-mail: jerzy.sikora@uni.lodz.pl
}

\title{
BiBLIOGRAFIA
}

Andrzejewska A., Kajzer L., (1995), Badania zespołu podominikańskiego w Brześciu Kujawskim, „Archaeologia Historica Polona”, t. 1, s. 127-148.

Banaszek Ł. (2014), Lotniczy skaning laserowy w polskiej archeologii. Czy w petni jest wykorzystywany potencjat prospekcyjny metody?, „Folia Praehistorica Posnaniensia", t. 19, s. 207-252.

Bednarczyk J. (1979), Ceramika naczyniowa, [w:] A. Cofta-Broniewska (red.), Zaplecze gospodarcze klasztoru oo. Franciszkanów w Inowrocławiu od połowy XIII do połowy $X V$ w. Wydawnictwo Naukowe Uniwersytetu im. Adama Mickiewicza w Poznaniu, Poznań, s. 56-116.

Bieniak J., Szymczakowa A. (oprac.) (1985), Urzędnicy tęczyccy, sieradzcy i wieluńscy XIII-XV w. Spisy, [w:] A. Gąsiorowski (red.), Urzędnicy dawnej Rzeczypospolitej XII-XVIII wieku. Spisy, t. II, Ziemie tęczycka, sieradzka i wieluńska, z. 1, Urzędnicy łęczyccy, sieradzcy $i$ wieluńscy XIII-XV wieku, Zakład Narodowy im. Ossolińskich, Wrocław-Lódź.

Bronk Ramsey C. (2013), OxCal 4.2, http://c14.arch.ox.ac.uk/oxcal (dostęp: 2.07.2018).

Chmielowska A., Góra M. (2009), Osada produkcyjna z okresu wczesnego i późnego średniowiecza $w$ Bogustawicach st. 7 pod Wolborzem, „Prace i Materiały Muzeum Archeologicznego i Etnograficznego w Łodzi”, seria archeologiczna nr 44 (2008-2009), s. 125-218.

Dębska-Luty K. (1972), Badania wykopaliskowe w Poznaniu na posesji przy ulicy Szewskiej 6, w roku 1960, „Fontes Archaeologici Posnanienses”, t. 22 (1971), s. $144-167$.

Dzieduszycki W. (1982), Wczesnomiejska ceramika kruszwicka w okresie od 2 połowy $X$ w. do połowy XIV w., Zakład Narodowy im. Ossolińskich, Wrocław-Lódź.

Dziubek E. (2011), Analiza artefaktów wczesno i późnośredniowiecznych ze stanowiska 5 w Pęcławicach, pow. Łęczyca, woj. tódzkie, [w:] E. Dziubek, I. Marchelak, L. Tyszler, Ratownicze badania archeologiczne na stanowisku 5 w Pęctawicach, pow. Łęczyca, woj. łódzkie (trasa autostrady A-1) (=Via Archaeologica Lodziensis t. IV), Fundacja Badań Archeologicznych im. K. Jażdżewskiego, Łódź, s. 71-153.

Horbacz T. (1997), O niektórych „kopcach historycznych” w Sieradzkiem w kilkadziesiąt lat później, „Archaeologia Historica Polona”, nr 5, s. 69-82. 
Horbacz T.J., Lechowicz Z. (1982), Przyczynek do problematyki osadnictwa późnośredniowiecznego i nowożytnego w rejonie Dmosina, województwo skierniewickie, „Rocznik Łódzki”, t. 32, s. 275-303.

Kajzer L. (1972), W sprawie genealogii wiejskiej siedziby obronnej w Polsce, „Kwartalnik Historii Kultury Materialnej” r. 20, nr 3, s. 451-465.

Kajzer L. (1980), Studia nad świeckim budownictwem obronnym województwa łęczyckiego w XIII-XVII wieku, „Acta Universitatis Lodziensis. Folia Archaeologica”, t. 1.

Kajzer L. (1986), Opracowanie zbioru ceramiki naczyniowej z „wieży Karnkowskiego” zamku w Raciążku, „Kwartalnik Historii Kultury Materialnej”, r. 34, nr 2, s. $199-225$.

Kajzer L. (1989-1990), Średniowieczny drewniany dwór obronny w Ortowie nad Bzura, „Slavia Antiqua”, t. 32, s. 241-290.

Kajzer L. (1990), Zamek w Raciążku, Budownictwo obronno-rezydencjonalne Kujaw i Ziemi Dobrzyńskiej, cz. I, Wydawnictwo Uniwersytetu Łódzkiego, Łódź.

Kajzer L. (1991), W sprawie waloryzacji masowych zbiorów ceramiki późnośredniowiecznej i nowożytnej, „Kwartalnik Historii Kultury Materialnej”, r. 39, nr 4, s. 467-484.

Kajzer L. (2004), Zamki i dwory obronne Polski centralnej, DiG, Warszawa.

Kamińska J. (1953), Grody wczesnośredniowiecznej ziem Polski środkowej na tle osadnictwa (= Acta Archaeologica Universitatis Lodziensis t. 2), Łódzkie Towarzystwo Naukowe, Łódź.

Kamińska J. (1966), Grodziska stożkowate śladem posiadłości rycerskich XIII-XIV w., „Prace i Materiały Muzeum Archeologicznego i Etnograficznego w Łodzi”, seria archeologiczna nr 7, s. 83-109.

Kamińska J. (1968), Siedlatków, obronna siedziba rycerska z XIV w., „Prace i Materiały Muzeum Archeologicznego i Etnograficznego w Łodzi”, seria archeologiczna nr 15, s. 15-88.

Kapusta E. (1997), Ceramika naczyniowa z zamku w Brześciu Kujawskim na tle specyfiki późnośredniowiecznej i nowożytnej ceramiki kujawskiej, „Acta Universitatis Lodzienis. Folia Archaeologica", nr 21, s. 131-166.

Łozinśki J.Z. (red.) (1954), Katalog Zabytków Sztuki w Polsce, t. 2, Województwo łódzkie, Państwowy Instytut Sztuki, Warszawa.

Kaźmierczyk J. (1970), Wrocław lewobrzeżny we wczesnym średniowieczu, t. 2, Zakład Narodowy im. Ossolińskich, Wrocław-Warszawa-Kraków.

Kittel P., Sikora J., Wroniecki P. (2018), A Late Medieval motte-and-bailey settlement in a lowland river valley landscape of Central Poland, „Geoarchaeology”, w druku, DOI:10.1002/gea.21676.

Kozierowski S. (1926), Badania nazw topograficznych na obszarze dawnej wschodniej Wielkopolski, t. 1, Poznańskie Towarzystwo Przyjaciół Nauk, Poznań.

Kruppe J. (1961), Studia nad ceramika XIV wieku ze Starego Miasta w Warszawie, Zakład Narodowy im. Ossolińskich, Wydawnictwo Polskiej Akademii Nauk, Wrocław-Warszawa-Kraków. 
Kruppe J. (1967), Garncarstwo warszawskie w wiekach XIV i XV, Zakład Narodowy im. Ossolińskich, Wydawnictwo Polskiej Akademii Nauk, Wrocław-WarszawaKraków.

Kruppe J. (1981), Garncarstwo późnośredniowieczne w Polsce, cz. II, Zakład Narodowy im. Ossolińskich, Wrocław-Warszawa-Kraków-Gdańsk-Lódź.

Leciejewicz L. (1962), Poczatki nadmorskich miast na Pomorzu Zachodnim, Zakład Narodowy im. Ossolińskich, Wrocław-Warszawa-Kraków.

Łaski J. (1881), Liber beneficiorum archidyecezyi gnieźnieńskiej, t. 2, wyd. ks. Jan Łukowski, Lange J.B., Gniezno.

Łosiński W., Rogosz R. (1986), Próba periodyzacji ceramiki wczesnośredniowiecznej ze Szczecina, [w:] J. Gromnicki (red.), Problemy chronologii ceramiki wczesnośredniowiecznej na Pomorzu Zachodnim, Wydawnictwa PKZ, Warszawa, s. 51-61.

Marciniak-Kajzer A. (2011), Średniowieczny dwór rycerski $w$ Polsce. Wizerunek archeologiczny, Wydawnictwo Uniwersytetu Łódzkiego, Łódź.

Matriculorum... (1915), Matricularum Regni Poloniae Summaria excussis codicibus, qui in Chartophylacio Maximo Varsoviensi asservantur, cz. IV/3, wyd. T. Wierzbowski, Warszawa.

Nawrolski T. (1978), Stan i problematyka badań nad produkcja garncarska na Pomorzu Zachodnim w późnym średniowieczu, „Archeologia Polski”, t. 23, z. 1, s. 141-182.

Nowak T. (2003), Własność ziemska w ziemi łęczyckiej w czasach Władysława Jagietly, Wydawnictwo Uniwersytetu Łódzkiego, Łódź.

Opaliński E., Żerek-Kleszcz H. (oprac.) 1993, Urzędnicy województw tęczyckiego i sieradzkiego XVI-XVIII wieku. Spisy, [w:] A. Gąsiorowski (red.), Urzędnicy dawnej Rzeczypospolitej XII-XVIII wieku. Spisy, t. II, Ziemie tęczycka, sieradzka $i$ wieluńska, z. 2, Urzędnicy tęczyccy, sieradzcy $i$ wieluńscy XVI-XVIII wieku, Polska Akademia Nauk. Biblioteka Kórnicka. Instytut Historii, Kórnik.

Pawiński A. (1883), Polska XVI wieku pod względem geograficzno-statystycznym opisana, [w:] Źródła dziejowe, t. 13, Wielkopolska, t. 2, Gebethner i Wolff, Warszawa.

Reimer P.J., Bard E., Bayliss A., Beck J.W., Blackwell P.G., Bronk Ramsey C., Grootes P.M., Guilderson T.P., Haflidason H., Hajdas I., Hatt Ž.C., Heaton T.J., Hoffmann D.L., Hogg A.G., Hughen K.A., Kaiser K.F., Kromer B., Manning S.W., Niu M., Reimer R.W., Richards D.A., Scott E.M., Southon J.R., Staff R.A., Turney C.S.M., van der Plicht J. (2013), IntCal13 and Marine13 Radiocarbon Age Calibration Curves 0-50,000 Years cal BP, „Radiocarbon”, 55(4), s. 1869-1887.

Rębkowski M. (2007), Chronologia ceramiki. Uwagi na podstawie zbioru uzyskanego w wykopie badanym w 1997 roku, [w:] L. Leciejewicz, M. Rębkowski (red.), Kołobrzeg. Wczesne miasto nad Bałtykiem, Trio, Warszawa, s. 199-213.

Rogosz R. (1981), Osadnictwo wczesnośredniowieczne na terenie Trzebiatowa w świetle badań archeologicznych, „Materiały Zachodniopomorskie”, t. 27, s. 71-149.

Rogosz R. (1986), Stargard nad Ina w świetle analizy chronologicznej ceramiki, [w:] J. Gromnicki (red.), Problemy chronologii ceramiki wczesnośredniowiecznej na Pomorzu Zachodnim, Wydawnictwa PKZ, Warszawa, s. 118-145. 
Sęczys E. (2000), Szlachta wylegitymowana w Królestwie Polskim w latach 1836-1861, DiG, Warszawa.

Sikora J. (2015), Peryferia w centrum podzielonego Królestwa. Archeologia Polski Centralnej dwunastego i trzynastego stulecia, „Fontes Archaeologici Posnanienses", t. 51, s. 125-147.

Sikora J., Kittel P. (2017), Problem nieco zapomniany? Zaplecza rezydencji rycerskich typu motte, [w:] A. Różański (red.), Gemma Gemmarum. Studia dedykowane Profesor Hannie Kočce-Krenz, Wydawnictwo Poznańskiego Towarzystwa Przyjaciół Nauk, Poznań, s. 561-589.

Sulkowska-Tuszyńska K. (1997), Średniowieczne naczynia ceramiczne z klasztoru norbertanek w Strzelnie, Wydawnictwo Naukowe Uniwersytetu Mikołaja Kopernika w Toruniu, Toruń.

Tomczak A. (1997), Zarys dziejów parafii Gieczno do roku 1939, Wydawnictwo Naukowe Uniwersytetu Mikołaja Kopernika w Toruniu, Toruń.

Uruski S., Kosiński A.A., Włodarski A. (1913), Rodzina. Herbarz szlachty polskiej, t. 10, Gebethner i Wolff, Warszawa.

Uruski S., Kosiński A.A., Włodarski A. (1917), Rodzina. Herbarz szlachty polskiej, t. 14, Gebethner i Wolff, Warszawa.

Zajączkowski S., Zajączkowski S.M. (1966), Materiały do słownika geograficzno-historycznego dawnych ziem łęczyckiej i sieradzkiej do 1400 roku, cz. I, Łódzkie Towarzystwo Naukowe, Łódź.

Zapłata R., Ptak A. (2015), Dziedzictwo kulturowe w świetle danych ALS. Zasoby ISOK w badaniach rejonu Bobolic: metodyka, analiza i wyniki, [w:] M. Pawleta, R. Zapłata (red.), Nieinwazyjne rozpoznanie zasobów dziedzictwa archeologicznego: potencjał i możliwości, Uniwersytet im. Adama Mickiewicza w Poznaniu, Fundacja „5Medium”, E-Naukowiec, Lublin, s. 99-140.

\section{Źródla internetowe}

Geoportal.gov.pl, http://www.geoportal.gov.pl/ (dostęp: 2.07.2018).

QGIS, http://qgis.org/ (dostęp: 2.07.2018).

RVT, Relief Visualisation Toolbox, http://iaps.zrc-sazu.si/en/rvt\#v (dostęp: 2.07.2018).

SAGA GIS, http://www.saga-gis.org/ (dostęp: 2.07.2018). 


\section{SUMMARY}

\section{LATE MEDIEVAL POTTERY FROM MOTTE IN GIECZNO, COMMUNE AND COUNTY ZGIERZ, ŁÓDŹ VOIVODSHIP}

A Late medieval motte-and-bailey timber castle in Gieczno was recognized by an analysis of the LiDAR derived Digital Terrain Model in 2014. The stronghold's remnants are situated in the Moszczenica River valley, on a small hillock - most probably the residual terrace. It is preserved as a small mound, elevated no more then $1,5 \mathrm{~m}$ above the surrounding floodplain in the bottom of the valley. The mound has dimensions of $31 \times 33 \mathrm{~m}$ and an area of about $890 \mathrm{~m}^{2}$. It is surrounded by a moat, about 8 to $10 \mathrm{~m}$ wide, and an adjacent low rampart not exceeding the height of 0.5 in relation to the bottom of the moat. The course of the rampart is interrupted in the south-eastern part. Another small, oval hillock with dimensions of approximately $23.4 \times 37.9 \mathrm{~m}$ is noticeable there. This find should be interpreted as remains of a motte and bailey castle with an economic area which supplemented the mound.

In 2015, a field investigation was run by Jerzy Sikora from the Institute of Archaeology of University of Łódź. During two weeks of field work, two trenches were explored:

Trench 1 (with dimensions of $1,5 \times 35 \mathrm{~m}$ ) cut the mound from its center to the South through the moat and the outer rampart in order to obtain a cross section of the feature.

Trench 2 (with dimensions of 12 x 1,5 m) was situated on the hillock (supposedly - motte) with the aim to recognize its stratigraphy.

During the excavation, a collection of Late Medieval potsherds was obtain (1472 pieces) together with a small number of metal finds, bones, slag pieces and a carved wooden artefact - a part of the Late Medieval furniture piece. An analysis of the collection helped to establish its chronology to the 14th and first half of 15 th centuries. The collection was distinguished by a significant number of potsherds made with the use of traditional methods and a relatively low amount of potsherds fired in a reducing (oxidizing) atmosphere. This indicates ties with the local, rural workshops rather than with the advanced manufacturing known in towns.

The excavations of the Gieczno stronghold revealed two phases of the feature:

- Phase I - the timber ringwork, protected with a small inner rampart, a palisade, a moat and an outer rampart can be dated by the radiocarbon analysis supported by an analysis of the finds to the 1st quarter of the14th century. 